\title{
The Value of Artillery in the Field
}

\section{Major-General C. H. Owen late R.A.}

To cite this article: Major-General C. H. Owen late R.A. (1889) The Value of Artillery in the Field, Royal United Services Institution. Journal, 33:147, 81-120, DOI: 10.1080/03071848909441230

To link to this article: http://dx.doi.org/10.1080/03071848909441230

\section{曲 Published online: 12 Nov 2009.}

Submit your article to this journal $\pi$

Џll Article views: 3

Q View related articles $₫$ 
Friday, February 8, 1889.

Gexr.ral Sir J. A. LINTORN SIMMONS, G.C.B., G.C.dI.G., R.E., in the Chair.

\title{
THE VALUE OF ARTIILERY IN TIIE FIELD.
}

\author{
By Major-General C. II. Owex, late R.A.
}

Tine ralue of nrtillery in the field as a porerfal instrament of destruction has been long recognized, at auy rate sivec Napoleon, and his able artillery commanders Senarmont and Drouot, showed what better organization nud iucreased mobility enabled them to accomplish with their guns at Friedland and in other battles.

During the long peace snceeding the Battle of Wnterloo little attention was paid to artillery tactics, and in this countrs field artillerg had been reduced to sucin a low point, that a fer Jears before the Crimean War it would hare been difficult to collect more than half a dozcu batteries for any expedition abrond. It was ouly in $18 t S$ that our troops of horse artillery were increased from two to four guns, aud in 18.52 both borse and ficld latteries were raised to six pieces, and the latter augmented to twenty batteries. This angmentation was obtained by Lord Hardinge, who had seen the great effect of artillery fire at Sobraon in 18.16, and who acknowledged that "if the thirty-six beary guns had not been brought to bear we should hare been repulsed." "The Russians maintained their belief in the power of artillers, and crushed the Poles at Warsaw in 1831 by the fire of a large mass of guns. They practised the same tactics on curselres at Inkerman, bringing a mass of guns ou our flank, the fire of which would doubtless hare cuabled their infuntry to dive us from our position had they not becn entangled in the rarines leadiug up to the beights.

The formidable power of artillery was demonstrated clearly in the Crimea, and after it very great interest was taken in all artillery matters, the fruits of which appeared in the use made by oursclves in Iudin and Chiua and by the French in Italy of artillers, and in the commencement of an unparalleled series of artillery experiments in this and other conntries. It is true that the Prussians in the war of 1860 were much behind the other Porrers in these respeets, their field artillery, partly smooth-bored guns, struggled along at the rear of the other troops, thes could not bo brought up in sufficient numbers into action, and wero not able to shoot when

VOL. XIYIII. 
there. The enormous improrements made after the war enabled it to render very great service to the other arms in 1870 , and since that time there is a tendencs to attribute every adrance in artillery practice or tactics to Germany. Well, many of us have been told to copy the French, Germans, or others in military matters, but we are apt to forget that these have often copied ourselres, and learnt a good deal from our Schools of Instruction, our experiments, our military literature, aud oren frow om sunall wars. Fortunately for us as a nation, but unfortunately for onr experience as soldiers, our troops hare nerer been engaged agninet. Furopean armies since the Crimean War, and neither Officers nor men, except a few of the former who served in the Crimea, have ever been under a heapy firo from artillery; this may account for the low estimato of field artillery now apparentls held.

After nll the instruction so larishly given to British Officers of tho present dar, I was under the impression that the increased power of the guns now used would be recognized, nnd that the iden of tho effect of artillery fire being chiefly noral had been exploderl a good many jears ago. I found, howerer, a short time since that I was mistaken. In na able lecture delivered at Aldershot last $A$ pril by Colonel Lonsdale Hale (late R.E.), I was not a little surprised to hear him use these words: " $A$ s regards the man-killing power of artillery, I am, I know, one of a few, a rers few, who believe in it;" and, when he goes on to say that this disbelief is in his opinion fraught with danger to the Arur, I feel sure many of us will share his opinion. For this disleclief Colonel Hale gate the following reasons:-(1st.) That few Otficers of infanty'y have not, in prepariner for promotion examinations, imbibed their artillers ideas from Clery's "Alinor Tuctics," which gives instances of artillery fire practically out of date. (2nd.) Impression produced by statistics of relative effects of infantry and artillery fire given in Colonel Ifone's "Pricis of Tactics," and Lord Wolseley's "Soldicr's Pocket Book," and otlicr works on tacties, the artillers fire being credited with only 5 per cent. of tho losses against 20 due to infintry fire. (3rd.) That many artillery Officers don't belicre in the man-killing power of their own weapons; and (4th, perhaps the grcatest) Lord Wolseles's opinion in his "Soldicr's Potket 13ook" thiat "the effect of artillery is more moral than nctunl ; it kills but fow:" I think I may safely say-that the instruction to be derived respecting the use of artillers as an arm, from some of the workis on tactics generally used, is of n very mengre kind.

A.s for the statistics of losses, I confess to have no faith in them. Colonel Brickeubnrs, R.A., in his ablo lecture at $\Lambda$ ldershot in June last, on tho: U:e and Abuse of Field Artillery," gare a long inble published in tho Reve. Jaritime et Colouinle, and, as he said, it has been since used by mally writers. It professes to gire the respective losses caused by firenrms and stcel in the wars of ' $6 \cdot 1$, ' 60 , and '70. Wut we should like to knww how the numbers were obtnincd? Whether thes included killed and wounded, or only the latter, as suegrested by Major Walford, R.A., in the discussion after the lecture? 'There are some manifest alsurditics; e.g., the I'russians suffered as much from 
mitrailleuse ns artillery (i.e., 5 per cent.); this would hardly be adnitted by them : it would also appear that ther had no losses from the sabre. Does this table include losses in siege as well as field operations? If so, the figures are of little raluc, as there were no siegres in 1866.

The Prussians by their artillery cansed, necording to the table of losses, 10 per cent. of the Danish losies in 18ut, only 3 per cent. of Austrinu losses in 1866, but 25 per cent. of French losses in 1870 , showing that the offect of their tire had declined aud reached a very low ebb in 1806, but hal inprored grently in 1870. So far it ngrees generally with the accounts given hy those who took part in these wars, but it rather looks as if tho table had been made to square with the accounts. Prince Kraft, speaking of the losses suffered by the lnrige mass of artillerr, 210 guns, at. Vionville (Mars-la-Tour), where it was constantly within range of energetic infautry fire, says : "I hare no means of knowing how large n part of the enomous losses of this artillers, in that hattle, was due to artillers, and how much to infantry fire." If the table liad been compiled from necurate statistics, Prince Kraft would hasc lad the meaus of knowing. But le roes on to say that, as it had alone to repulse many infantry attacks, the greater part of its loss was due probably to tho Chassepot fire. He makes a guess from his experience at Saint Prirat, where the batteries of the Artillers of the Guard, which lost 25 per cent. of the horses nud 20 ger cent. of the men present in the battle, attributed 75 per cent. of thic loss to Chassepot bullets. This pereentage docs not angree with that in the table, which gives 88 as tho percentage of losses caused by French infantry firc, and this was a case inost farourable to it, for, "whilst these batteries were, from 2 P.X. until nearly 6 P.ss., standing in position under fire in front of Saint Privat, three French battalions, all extended in shirmishing order, lay in their fiont at a range of from 900 to 1,0 no paces, all their meu being corered by the fences between the fields. A similar line lay 100 jards in rear, and a third farther back still. 'l'he foremost of these three lines fired without ceasing at tho batteries." If we take a case farourable to artillery fire, as Sedan, we find militury wilers, both German and French, just after the war attribute the great losses of the French especialls to artillery fire; nnd the correspondent of the "Daily News," tiding over the field the day after the action said: "The ghastly wounds inflicted on most of the French dead whom I saw upun the hill showed that they had fallen under an artillery fire; nnd the ground wns in mauj places so ploighed up that a blanket could scarcely have been laid on it without covering some spot where a shell had exploded."

If I hare dwelt on this table of losses longer than may seem necessary, it is because, in the discussion on Colonel Brackentuury's lecture at Allershint on the "Use and Abnse of Artillery", it was quoted ly Isourl Wolseley nut only to disparage the dingrim of effects of shell fire shown, lout to prove that "the effect of nitiliery is noore mornl than actuctl." IIe siss in his "Pockct Book" (p. 359, 8th Edition): "This should be coustantly pressed on the miuds of you a 2 
infantry soldiers;" and he quotes at p. 121 the instance of Grarclotte; where it was said 90 per cent. of killed and wounded were hit hy bullets and only 6 per cent. by artillery fre. Supposing this to be correct, it may bo pointed out that at this battle the Germans attacked in some instances in columns, that Baznine beld back a finc rescrve of artillers, and that the French fired common shell or ineffective shrapnel. The reason for inpressing the above so-called truth, on the infantrs especialls, comes out at p. 12l, vi\%:- to "put a stop to the rry for wore guns which one still hears occasionally." I am if raid this ery for innro guns, ns well as men and horses, will bo heard pretty loudly if we find ourselves at war with a Contiuental nation.

. If we want to form a just estimatc of what artillery did as an arm iu recent Continental wars, it is better, instend of trusting to doubtful tables of losses, to examine carefully the reports and accounts of thuse who actually served in those wars, or wrote from sound infor. ination at the time. There are plents of such sources of information respecting the war of 1870-71 in the oflicial acconnts, and in those of IIoffbauer, Boguslarsbi, Riistow, Frossard, De Wimpffen, Nieman, and others; and fortunately, as far as artillery is concerned, the subject lias been exhaustively treated ly Princo Kraft za Hohenlohe Ingelfingen in his "I,etters on Artillery;" a good translation of which, by Lient.-Col. Walford, R.A., is to be found in tho "Procecdings of the Royal Artillerg Institution" of last jear." You are all probably aware that Princo Krnft is considered onc of the ablest artillery Officers in Europe, as far as field artillery is conccrned, having had ample cxperience in the commauds of largo numbers of batteries in the wars of $1866-70$, and having exerted limself most energetically dnring peace-time to inprove the German field artillery in all its branches, -organization, drill, tactics, and gunnery. The chief results to bo gnthered from theso "Letters ou Artillery" were pat forward by Colonel Brackenbury in his lecture on the "Use and Abuse of Field ditillers" at Aldershot.

Well, in all these works we may find numerous instances of a way being opened for successful nttacks by other arms, of infantry and cavalrs attacks being stopped or repulsed, of buildings and other obstacles being broken throngh or destrojed, of field artillers or machinc-guns being annibilated, silenced, or driven off by the fire of artillery, aud it should bo needless to say that moral effect could landly havo accomplished such things withont a considerable amount also of destructive effect. Although tho Seposs in the Indian Muting were, as Lord Wolseles snid at $A$ ldershot, inspired with confidence by hearing their own guns fire blauk castridge, I confess I don't think Frencl, German, or our own troops would be satisfied or terrified by inere noiso. The first time I was under a bears fire from artillery a round shot came shricking along, knocked the leader of the team of an am. nunition ragon of lis legs, rattled through the belly of a whecler, and dashed on as if it had done notbing; the moral effect was certainly

1 All quotations from Princo liraft's lettcrs are from this translation. 
rerg great, and $I$ had difficulty in getting the neen to disentangle the team; it was not, however, produced by the noise but by the ghastly damage done. Those who have seen service in warfare where artillery hus been emplosed, will, no doubt, acknowledge the great moral effect produced by its fire; and, as Colonel Brackenbury pointed ont at Aldershot-" It is not the number of the eneung killed aud wounded which cusures victory, bat the woral effect produced on the remainder." I and a good many others think nitillery may claim to inflict, beyond mere moral effect, a great deal of actmal damage to men, horses, and matéricl, if it be properly trained and handled well in action, bat the latter is impossible if its power be not acknorledged.

To judge what can be done at the present time by artillers in the field, we mast take into account the inprovements made during recent years in guus and ammunition, and, what are of eqnal im. portance, the pains taken to train and instruct both Officers and men in warching, tactics, and gunners; so that in future we shall have to deal, if engaged in a Contiuental war, with more formidable artilleries than that of the Germans which produced such great results in 1870 . Colonel Brackenbury exlibited instructive diagrams, showing the number of hits on targets at different ranges made by the slirapuel shell and case shot now used. The latter struck me especinlly as being far more numerous than I should bare expected. 'These diagrams were said to have produced quito a nightmaic at Allershot, so I have refrnined from borrowing them for this afternoon. It is trne that the tnble of losses appeared to renssure some of the speakers, but I think I have shown it is not rers trustnorthy, and in any case would hardly apply to the future.

In the war of 1866 the German artillery were badly handled and could not shout, and in 1870 , although it was well handled and shot with precision, it ficed but rery fen shrapnel shell, and had, I think, no time-fuxcs; while the Freuch fired a good number of shrupnel, bnt with fazes only adapted to a ferr ranges, and could not therefore be effective. I thiuk but scant justice has been done of late to Genemal Boxer, K.A., who made so many improrements in the shell and fines, and I do not hesitate to say that had British artillers taken part in these wars, the enemy would have been considembly astonished by our shrapuel fire, and would hare suffered much from it. $\lambda$ t that time ouly oursclves and the $A$ ustrians put the bursting charge at tho base of the shell. I myself fired spherical shrapnel shell with terriblo effect over the heads of our assaulting troops, at the lcft flank of the Redan, 35 jears ago, and our field batteries used shrapnel in the Crimean war; and during the Mutiny in India we fired shrapnel at Luct now with the fuze inwards to act as calse, $n$ similar method to that (sctting the fnze at zero) recommended by Prince Kraft now, and which has long been understond in onr Service.

The rifled guns first introduced, aud those used for many years after, were fired with small clarges compared to those of the old smonth-bored guns; and even in 1866, mnny of the German Oflicers, who were then much behiudhand in artillery matters; contended that 
there should always be, as they liad at that time, a certain proportion of smootl $1_{1}$-bored field guns, for shrapnel and case, owing to the low velocity given by the small charge of their rifled guus, which were not effective.

Now, in consequence of the large charges and better adaptation of the powder and dimensions of the burc, very high velocity is giren to the shells, and this has immensely incecascd tho power of shrapnel shell firc. These shells can be fred with destructive effect at much lonerer ranges and at lower angles of eleration, so that moro ground is rendered dangerous by the bullets after the surll bursts; and I am told that they can brcak througl shelter-trenches, buildings, and obstacles of small strength, and still be effectire iuside of them, cren with percussion fuzes, which would have been useless with the shrapnel from the older guns. We thus see that thero has been, during recent sear's, the derelopment of a more dest ructive fire from artillery. There would bo a disadrantage in the high velocity if firing from below at troops or guns posted just behind a ridge, and in some other cases, and there might be premature bursting, a serious thing if fring over the hends of our own troops; but I understand that with the steel shrapnel now enade it does not occur; on the contrary, the shell does not break on explosion, which is a disadvantage. I stated this objection of premature bursting some jears ago in the discussion after an able lecture in this room by Jinjor-Genernl $H$. Brackenbury. There is nlso another disidsantage resulting from very high relocities, viz., greater ditticulty in regulating fuzes, the intervals of time corresponding with differences in ranges being so wuch less than with the luwer velocities. The bursting chargo is placed in the lead of this shell, to grive ronm for a few more bullets; but this is against the principle of the shrapnel, and must cause retardation of the ballets.

In au attack on an entrenched position, or in firing at gnns or troops posted or moving in ground pretts well sheltered from shrapnel fire, or at artillery either in tho opeu or in gun-pits, common shell will have to be used. Remember that the effect of a common shell on explosion acts all round, while that of a shrapnel lies mainly in a forward direction. The force from the explosion of a common shell is capable of dismounting guns and destroying carriages, while the flame explodes amnianition boses, and sets fire to combustible objects. Aud I can assure you from experience that the explosions of shells, drupping orer corer and bursting, so as to hit those apparently under secure shelter, lave a demoraliziug effect not to be despised. This is especially so with vertical fire; I am not going to propose mortars for field service, but I hare long thought that a few batteries of riffed lowitzers, firing shells with large hursting charges, would bo of en valuable in the feld, especially for at tacks on entrenched positions ; for being fired with sinaller charges and at bigher angles than shrapnel shell, they could reach objects quite secure from tho latter. 1 cannot see the object of firing common shell with very high velocities in the feld, the effect on men and horses under corer, or on guus, wagrous, ordinary buildings, de., being thereby diniuished. I 
should think it vers doubtful whether tough stecl is a good materinl for common or other shells. Then the effect of sbells can be increased by haring bursting cliarges of mélinite or other more powerful explosire substances than gunpowder. I nn told by the best autho. rity in this country that the application of high explosives in shells is being rapidly and successfully dereloped; this will bo a means of greatly increasing the power of artillery.

It is sometimes objected that coninon shells are liable to bury themselves harmless/g in the ground, with or without bursting, as many did in the actions during the war of 1866 ; but that many of the Prussian shells were blind is not very surprising, for Prince Kraft sajs: "I could also name to you some linge bodies of artillery whose shells were blind, simply becruse, in the projectiles furnished at the reuewal of their ammunition from the columns, thes had forgotten, as was afterwards discovered, to insert any percussion arrangement." And he adds, "it is difficult to see how the shells could have been expected to burst." Fuzes are sometimes said to be defectire when the fault has arisen from irregularity in boring or setting them.

It will be of little use to liave powerful guns if Officers and men are not thoroughly trained in gunnery, so as to cmploy them in the most efficient way. An artillery that goes into the tield at the present tiuc, withont the requisito gunnery training, will be very soun knocked to pieces by an opponent who has acquired the art of shooting, notwithstanding any superiority in armament the former may possess. Although Prince Kiaft mas now teach us a great deal, founded on his aurivalled experience in the command of artillery in war, there is littlo doubt but that he and other Oflicers of the Prussian artillers, who effected such a transformation in their systems of both gunnery and tacties hetween the wars of 1866 and 1870 , learnt a good deal from us. Long after the establishment of our School of Gunners at Shoeburyness, ${ }^{1}$ the decelopment of the artillery conrse at the Jinyal Jilitary Academ5, Woolwich (in which I had some share), nud the fuundation of the Rosal Artillery Institutiou, and of this Institution, for distributing throughout the Service artilley liternturo of the most valuable kind-the Prussinn artillery was in the most benighted condition. Independent's of taking their tactics from the war-time of 1815 , their Sclool of Gunnery was not formed on an adcquate basis till after the war of 1866 had sliown such lamentable deficiencies in shooting; and then, as Prince Kraft teils us, "a singular finte was rescried for the scientific arm. It bad to acrept the principles of the unscieutific infantrs, the rilled fircarm, and the breceb-loader, and also their method of theorctical instruction," and "that n number of instructors bad first to be taught," and that "the sear 1867 was nearly over hefore a sufficient number of instructors had been provided to teach the troops a rational munner of shorting."

Notwithstanding the raluablo resnlts accomplished by our School of Gunnerg at Shocbuljness, it has two disadratatages. Oue, that it 
is combined with the Lxperimental Department; this is an adrantage itself in some ways, as the courses and batteries trained there can acquire some ac:quaintanco with the new matériel introduced from time to time; but, on tho other hand, one department unust interfere moro or less with the other as regards convenience of practice, and $J$ have often noticed it when thero in command of calets or field batteries. Tho second disadrantage is that a flat range orer sands is a rerg imperfect one for field artillery practice, as it does not represent the conclitions of service. But the Government touk the wise step, in 1877, of forming annual prictice camps at Hay and Obehampton, where feld batteries can be tritined on ground such as would bo met with in nctual warfare; in these they can be taught to fire at. dumng troops or guns, on different kiuds of ground, at varying lerels. in the open, or protected by shelter-trenches, gun-pits, parnpets of eartinworks, or behind folds in the surface.

Careful instructious are laid down for the practice of horse and field artillery at these practice camps, and four deseriptions of practice are carried on, riz., elementary, competitive, battery service, and brigade service. The two Jatter are conducted, as far as possible, undor servico conditions, and as thes are at unknown distnnces, a method of finding the range, called ranging a battery or brigade, is adopted, consisting in three processes: (a) finding the long bracket, (b) finding the short bracket, nud (c) rerifying tho range; the bracket being the distance between the ranges of trio sliells, ne under and one over the object. Our batteries are provided with rnnge-finders, and hare obserring parties which, by signalling, can show the rffect of the fire; and to test the supply of ammunition from the warons, the full number of rounds to be fired is not earried in the limbers.

The Gerrians lay much stress on practice at moring targets, not merely crossing the front at right angles, but obliquely, and advancing towards the battery, and selecting some point of ground over which the target must pass, and laying the guns on it; as we should do in firing from a const batters on a ressel in motion attacking or passing it. They do not appear to attach so much importance to ranger-finders in the field ns we do, trusting to tho burstings of common shells. These methods of firing at targets moving in different directions are laid down in our Ficld Artillery Drill Book and in the iustructions for our practice camps, and are carried out there by the batteries.

Mitherto four horso or field artillery battcries practised annunlly at Hay, and nine batteries in three divisions at Okehampton; but as Hay is ansuitablo for 12-pr. B.C. or 13-pr. MI.L. gans, thirtecn batteries will go to Okehampton this yenr.

It ouly remains to take full advantage of these practice camps. It is said that the shooting season miglit be lengthened bs adding a month at the beginning and another at the end; that more batteries might be sent at one time; and that thes might be kept more continuously at work while there. These would involve increased expenditure of ammnnition, and the steel slimpnel shell are each costly, but much of the practice can be carried on with the ordinary 
cast-iron shells. Elementars practico in loading, laying, and firing a gun at targets at known or unknown distnuces can be done on any ordinnry range like that at Shocburyness. These machine-gans and magazine rifles should be tried against artillery, and for this parposo somo infitutry might be sent down to Okeluampton. There is said to be little practice at anseen objects, and yot a suflicient variety in tho works fired at.

We hear a grent. deal now about qnick-firing guns, and thes are doubtless formiduble wenpons in fortresses, const batteries, and ships, but I cannot see how they could bo used to any extent in the field, as they require to be fired continuonsly from the same position withont recoil. I hine often thought that onr field carriages might be improsed by haring recoil slides or some arrangeuent for lessening recoil. If the recoil could be prevented, both accuracy nud mapility of fire would be incrensed, the labour of ranning up would bo aroided, and gans could be placed, as Captinin Stone has pointed out, in positions otherwise impracticable.

'The nou-recoil carriages now mado by Nordenfelt, $\Delta$ rmstrong, and other companies are a great advance as far as thes go; but although the compressors and breaks stop the rnnning back, they do not prevent motion suflicieut to throw out the lasing to some cxtent, and the strmin on the carriage puts a limit to the calibre of gun that can bo fired from them. A 6-prr. is the gan recommended for horse artillers, but the shells of such a piece would bo insiguificant compared to those of the 12-pr. service guns. Thes might, as their adrocates sny, fire a greater weight of metal in a given time, but I think this is a fallacious comparison; and great carc would have to be excrcised to prerent quick firing being indulged in too often, or for too loner a time, with conscquent ranning out of nammutios. No doubt qnick. firng guns are admirably adapted to some parpuses for which horse artillery are employed-adranced guards, retreats, surprises, de.; but horse artillery nre often wanted to join the lino of a mass of guns, and to oppose powerful freld-pieces. Quick-firing gnns have the great adrantage of requiring so few wen to work them, and being free to move in any direction, of giving great facility for following objects in motion.

'Then with respect to the Maxim, the latest derelopment of the machine-gun, wo heard that Mr. Marim, in reply to Lord Wolselcy's remark, "If sou can invent a machine-gun which will pump lead on troops or guns at a distance of 3,000 jarils you will ereate a new departure in all the military tactics in the world," said, "that he hind done it;" nnd, further, "that I will not only puinp lead 3,000 yards, but also 4,000 sards, with great facilite." It may, howerer, be suggested, that artillery might be nule to return this storm of lcad with the addition of a certain amount of iron, explosion of shells, and fragments, that might serre to knock the Maxin machine-gans ghout, damago thcir action, and dismount them; also that infantrs or cavalry wonld uot be inclined to remain qnietly exposed to such a storm as a tnrget for the Mnxim gun. I nm quite rendy to allow that the Maxim gun is a very formidable weapon. when used atginst any troops at 
comparatirely short ranges, if thry are in pretty close formations and in confued situations, but at long ranges the ceffect canuot be observed, and their fire is of little use against matéricl, whereas if struck by shell they are very lisble to be disibled.

Of the effect produced by the ritled field artillers of the French in the war of lojog, or of that by the lirecch-loading small-arms of the Prussians in 1866, there was no doubt; but it call hardls be said that the war of 1870 k'ns much influenced by the French mitrailleuses, although thej at times caused a great deal of destruction. In my work on "Mlodern Artillery, 1873," I gave a number" of iustances, collected at the time, of the enployment of nitrailleuses in action. One was as follows:-At Gravelutte, a mass of German batteries (84 guns) cane into nction against a somewhat similar number of French guns nnd a battery of mitritlleuscs. "As the batteries galloped up, vast numbers of French shells burst short in the air, or on the ground in rear, but struck nobods; a continnous min of mitmillense bullets also fell into a particular hollow behind them where nothing was; lut the German commander of the first three batteries in action Fir cied their whole fire to be giren together on the first French mit : itlleuse on the right; thereapon, a confused storm of esplosions wa: seen to spring all over where the nitrailleuse had stood, succeded onl. by a racint space with some wreck on the ground; the samo trei ment was adopted with the second and third mitritileuses, on whi ht the fourth vnuisbed of its owu accord.". 'l'he repid destruction of the unachino hattery was not confirneed by Froissard, but he admits that it lost a great mans men and horses, and had to be withdrawn with the aid of the French jnfantry supporting it, and it is erielent that its fire did vo harm. On the other hand, some witrailleuses held their ground agninse artillery aud repulsed infantry, but they were behind cpaulments on the beights of Villette.

It may be said that the Maxim gun is a great improvement on tho French mitrailleuse then used, but small-itrms aud feld-guns laave been also greatly improved since 1870 .

In the discnssiov affer Captinin Slone's lecture at Aldershot, Jajor IIntion stated, that althongh the Fordenfelt gun made exrellent practice on a level range, their effect wils sinall at ranges of 1,450 and 1,120 yards when fired on ground under service conditions, the distances being acenrately found with a range-finder; this was attributed to the wheels of the carriage not being level, but the firing party thought they had done considerable cxecution. I'his ignorance of what you are doing is a great objection. Then Jnjor Jlecham stated that the smoke was so deuse that the target was hidden, hut this difticulty might be obviated by using smokeless powder; he also stated, that at 100 or 500 and 1,101 yards the rifles of infantry made much better practice than the machine-grnn.

Jajor Ilution also give an instince from the war in Fegjpt, where the machine-gans had to stop firing, as they dropped their bullets amoug their own infantry, over whose heads they were firing, although

1 Tuten from "Obscrations aunongst German drmies during 16j0," by Colonel H. A. Suyth, R.L. 
the ranges could be easily calculated by telegraph poles. I agrec with what Mr. Nordenfelt said, that " the rifle calibre gun will not take the place of the shell-firing gan."

A few machine-guns miglit be nseful with tho infantrs escort for artillers, in beeping down infantry fire upon the gans, and resisting any sudden rush apon them. Some infantry Officers say that machine-guns attached to infantry rather tend to impede them, as infantry can move over ground impracticable to carriages; but organized in small batteries, as saggested by Captain Stone, they might greatly assist infantry or cavalry in close action.

We now como to the ranges at which gans sloould be fired in the ficld. In tho first edition of my work, "Alodern Artillers," published in 1870 , I put them at from 1,000 to 2,500 yards, and for position guns some hundreds of yards further, always insisting that the longest effective ranges shoold be chosen when practicable; and, as these agreed with those laid down by Prince Kraft in a pamphlet he wrote shortly after the wal" of 1870, entitled "The Employment of Field Artillery," I kept to them in the edition of 1873 . I added that in some cases when guns wero attucked by infantry or carairg, or if thes could bo brought saddenly on tho tanks of an enemy's troops, very short ranges might have still to be used, but that breech-loading small-arus and machine-guns should vender runges ander 1,000 yards very dangcrous to artillery. Now that field-gans giro such high relocities to their sliels, greater effective ranges can be employed, and we mas, I think, accent with confidence those given by Prince Kraft. He says: "The effect of artillery is noticeable at 5,500 yards. The effect of surapnel begins at about 3,800 yards, and at from 2,000 to 1,500 Jards is decisire, while at frorn 1,100 to 1,000 yards and under the offect of artillery is alssolutely aunibilating: always provided that its field of fire be open. Since shrapnel with the time-fuze set to zero have become so murderons in their results, the effect of artillery at rery sbort ranges, which had been diminished by tho former inferiority of the ense for rifled guns, has now again become annihilating." I don't know whether ho means to imply that case shot should be abolished, bat I do not think it would be wise to do so. I don't think shrapnel with fuzes set to zero are rery effectire nt ronges under 300 sards. I am no adrocate of very long ranges, which are apt to lead to waste of ammunition; and time-fuzes are not adapted to over 3,200 yards range.

Tie must, however, always remember that the effect of artillery fire, like that of other firearms, is influencerl by many circumstances in actual warfare, and not expect the saroe results as can be obtained on a practice ground. Battles are not generalls fought on level plains in fine calm weather with no smoke, dust, or noise, or the issue might be like that of the combat between Kilkenny cats. Battles are often fought in foggs or rainy weather, when field-glasses are of small use, and when objects cannot be ecen at long ranges. Both at Jnkerman and Sedan the engagement began in a fog. At the former the prnjectiles of the Russi:ns came crushing into our 2ud Division camp alnost as soou as the pickets were engaged, the enemy knowing the 
range; and at the latter, the Prussian guns could not at first open fire. Then high wind and heary rain both tend to disconcert acenrate practice. The next hindrances to accurate fire are the clonds of smoke and dust often hanging about, frnm the firing of guns and small-arms, the bursting of sleells, and the movernents of troops. Also the horrid noises cansed by these, and the frightful gaps made in bodies of men and horses, the destruction of gans and carriages, and the blowing ap of limbers and ammunition wagons, are enough to shake the nerves of the brarest troops, and make their shooting more or less unsteady. Besides these, the guns are not, as in sieges, fred from platforms, and must be run up after cach round, often on soft or rough ground. Those who think that the effect of artillery fire is chieds moral should remember that the fire of small-arms in battles is not always what might be expected from practice at a School of Musketry, and I think Lord Wolseles himself remarked on the iuferior shooting of the infantry in the Egjptian War.

Iord Wolseley has recently called attention to circumstances that may greatly modify the tactics required in future wars, but I think some of them are scarcely ripe for consideration, at least at present. He sajs: "One remarkable change will be the absence of nearly all that terrific noise which the discharge of 500 or 600 field-guns and the roar of mushetry caused in all great battles. We shall have practically no smoke to mark the position of the enemy's leatteries and troops in action. 'The sound of cannon will be slight, and will no longer indicate to distant troops where their comrades are engaged, or the point upon which they should consequently march. Our sontries and advanced posts can no longer alarm the main body upon the approach of the eneny by the discharge of their rifles." I don't think we have jet reached the time when there will be an absence of smoke in warfare. Powder giving off little smoke is used for sporting purposes, and the l'rench, ourselves, and others are working to perfect a smokeless powder, the explosion of which eauses less noise than that of ordinary gunpowder, and if it can be used with saccess, some modifications in tactics mas be necessary; but whether such porder can be made for ordnanco is questionable. I wrote to Sir. F. Aluel on this point, and from his official position he could only send me the following guarded reply, but it is sufficient for my purpose: "Comparativels smokeless powders are likely to come into extensive use for small-arms within a brief period; such powders do produce considerably less noise than black powder. It mould at present be premature to liazard an opinion as to the extent to which powders of that. description are likely to displace gunpowder of the present types in artillery."

That artillery will certninly not use smokeless powder for shells must be evident, for the smoke from the bursting of the shell is an admirable guide to rauge and effect, and the noise of the explosion only affects the enemy, and is therefore an adrantage, although it is but a moral one. As to other poises in action, there will alwass be the pings of the bollets, and the horrid screamings of the shells as they pass through the air. 
With respect to tiels artillery drills it is pretty generally admitted that they may be simplified with adrantage. I had the commaud of from two to six latteries for some years, and never attempted, yor asked other Officers to attempt, some complicated manceurres that would not be required in the field. Prince Kraft says on this poiut: "Judging by iny experiences in war, and you will own that in matters connected with artillery they are fairly numerous, the only movements which are of use in the fiold are, the adrance in column of route, deplosments, and the ndvance in line." I think you might add some others, such as change of front and methods of retiring. With what he sriys of the usclessness of galloping over short dis. tances we should most of us, I think, agree, increnses of a few lundred yards range being easily olbtained with our prescut guns without moring. What is clicfly wanted, as he points out, is wobility over long distarices in getting to the frent on the inarch. He says: "It is no longer, as it used to be, desirable to gain a few seconds, in order to fire the first shot quickly; on tho contrary, a long time is now- taken orer the first shots, in order to lay and obserse them quietly and accurately. It is now a matter of hours, which we must endeavour to gain in coming into action." Ho writes: "The introduction of rifed guns, and the experience whicb was obtained in 1866, considerably altered the demands which must be made on the mobility of the artillery. The necessity of employing the great artillery masses early at the beginning of the fight demands quickness of morement, not over distances of 200 , or at most 1,500 , paces, but orer distances measured by iniles and days' mareling." He mentions an instance when he bad to trot 14 linglish miles in order to come into action, in 1866 , but he adds: "Even greater demands than these must bo made upon the artillery when it is a question of moring artillery from one thank of the theatre of war to the other, or of sending them quickly to bodies of troops which hare been detached to a distance." "For cxample, the lst Horse Artillery battery of the Guard marched, on 13th Angust (1870), 32 English miles from Bermering by Aron to Dieulouard, where it encamped on the same erening."

It is satisfactory to find that the practice of making long marches at a quick pace is not nerglected in our Service. In December, 1887, Major Turnball's battery of horse artillery marched in India 47 miles in 9 hours and 40 minutes, exclusive of two halts of 1 hour and $1 \frac{1}{2}$ hour's, and three or four short lialts. The first 2 miles was across countrs, the rest orer a metalled road up and down hill. In order to make these long marches, horses must be in good hard condition, not merely fat and sleek, as is sometimes thought requisito for our inspections. Lord Wolseles's criticism on the burnishing of "ererlasting bright chains" may be just or not, but it is orident that larness must be cleaned properly or it will not last, and may gall the horses.

The importance of coming into action early and quickly caunot be orerrated, for batteries in action have a great adrantage orer those coming into action, and infantry will seldom dire to attack in frout a live of batteries in action. The Germans bold strongly that artilleryin action cannot be driren back by infintry. Prince Kraft sass: 
"There were huudreds and thonsands of cases in the war of 1870-71 where artillery which refused to retire could not be driren back by infantry fire;" aud, "I repeat once more, and I cannot too often repent, artillery cannot, spealing generally, ever be iviven back $b !$ infuntry if it refuses to leare its ground. On the contrars, when infintry fire is really hot, it caunot for the noment fall back, since so manj of its horses will then be shot. But, nerertheless, nothing is lost so long as there are a couple of men left with cach gun, who can load and lay quietly; it can thus go on doing its work until the last gunuer is disabled." He warns us, as Colonel Brackeubury pointed out, against the errors that grow up in a long pence, and the terrible harm which ompires do at peace manoenrres by ordering guns back when under the fire of infuntry.

The following instance is instructire as showing how artillery fire should be directed against adrancing infantry. Privce Kraft sass : "Standing behind the Captain of a battery in action, as troops were advancing to attack him, I heard him quictly give the order: "A gainst infantry in front, 1,900 paces from the right flank. Ready. Fire one gun.' Then he waited, holding his field-glass to his eye, until tho enemy approached the point on which the guns were laid, and gave the order: 'Rapid fring from tho right fank.' 'Then there was a hellish sight, for the adrancing enemy disappeared from view in the clouds of smoke which the shells throw up as they burst and toro their way through his ranks. After one or two minutes, the attacking enemy came out on our side of the smoke. It had passed the point on which the gans were laid, and, in spite of terrible loss, approached with undeniable brarery. Then the Captain gare the cornmund: 'Cease firing! 1,600 paces-one gun!-ceasc firiug!' and when the enemy drew near to the new point on which the guns were now laid, he cricd: 'At 1,600 paces-fiom the right flank, rapid firing!' 'The effect was brilliant, horrible, and overwhelming. No attack could have resisted it."

It seems to me that, although artillery may in most cases be ablo to defend its front, it does not follow that infantry cannot attack it successfully under rarious circumstances. Its position may be turned and infantry succed in getting on its flank at a few hundred yards range; and after the tirst furious artillery duel wany batteries will be more or less disabled, and perhaps ont of ammunition, when they might fall a prey to an infantry or caralry attack well execnted; lence the necessity of alwass providing a strong escort on exposnd flanks of a line of guns, and putting horse artillers on such fanks. At first when guns are firing at long ranges there will be no danger from other arms, but battles cannot be decided at several thousand yards distance, Aroops must come to close quarters, the battcries may have to advance and mas get entangled with other troops, or at any mate have their fire impeded by them, and opportusitics may arise which mas rive an cnterprising cucmy a chance of taking artillery at a disidvantasere.

Prince Kraft gives an instance from the Battle of Königgrïz: “' Fhanks to the impetuosity and the rapidity with which our infantry 
rushed to the front, the numerical supcriority of the enemy's artillery could not, for want of time, produce at this phase of the struggle such a tremendons effect as it did at other points and at other monents in the course of the hattle. It was, no lonbt, ou account of the vers high corn, and of the smoke produced by the rapid fire which it kept up on our batteries, that the Austrian artillery were not ablo to follow with the requisite attention the advance of our foremnst lines of skirmishers. It was these lines which, sudilenly and at alınost point blank range, orerwhelmed the enemy's guns with a rnpid fire, and captured 68 guns of this long artillery line (tho lst Division of the Guard tonk 55 and the 2nd Battalion of the 50th Regiment 13 guns). 'The others succeded in cscnping." The Prussinn gans were just opening fire, and seciner some $\Lambda$ ustrian limber boxes explode and their line of guus cense firing, Prince $\mathrm{Kraft}$ and others thought their artillery fire had produced this result; but the explosions were due to the explosice bullets of the Prussinn infantry. Hoff bauer gives an instnnce from the Battle of Mnrs-la-Tour of infautry inflicting considerable damage on artillery at a long range. He snys: "From the moment of passing the defile which runs fiom Flivigny towards the south-west, the Ist Horse Artillery battery suffered severely from hostile infintry behind a hedge 1,500 paces distant." This cnse of infantrs under corer and undisturbed quietly potting at a batters on the nore is no indication of the proper range for infantry to eng:tge nrtillery in netion.

If it is of importance to come into nction quickly, artillery serring mercly as a target while doing so, it is necessary that when in action the fire slould be deliberate at first while picking up the range, but when this is found the fre miny be rapid, the effect, howerer, always being carefully noted, and any necessary alterntions mnde in laying the guns and regulating the fuzes. There should be no salvoes rxept at close quarters, or mudom shooting of any kind. In firing on artillery several guns should be concentrated on one of the enemy's pieces until it is silenced, when the same fire should be turned on another:

The old rule was to fire common shell to damage or dismount gurs and carriages, and to blow ap limbers and wagons; and shrapmel shell to kill or wonnd incn and horses, and I seo no reason why it should not still apply. Now that shrapnel shell can be fired with percussion fuzes, which was not formerly attempted, they can also damagre matériel aud unight blow up anmunition boxes, but commnn shell woukl bo more effective for such purposes, and are less costly than shrapnel ; and Capt. St. J. Ord, R.A., who hins been Staff Officer at Okchampton firr three sears, tells me lie does not consider percussion shrilpuel suitable for firing against artillery, the intersals being too great and the bullets not haviuer a very widle dispersion. Hessys respecting firo at artillers: " (1.) If your cnemy's battery is in action in the open but no limbers or wagons visible, $i . e$. , just on the crest of a hill or a little way down the forward slope of it, then the propostion should be $\frac{13}{3}$ common to $\frac{1}{3}$ shrapnel, that is to sing, ont of every 6 rounds 4 shonld be comnon and 2 shrapnel, the great object being to 
dismount or damnge the enemy's guns. (2.) Supposing the enemy's battery is in action with its limbers and horses visible, then after finding the range ${ }^{l}$ I consider the right proportion to be $\frac{1}{3}$ common and 3 shrapnel, i.e., 2 common to 4 shrnpnel in cach 6 rounds. The shrapnel should do much damage to the horses, always a very large target, and, with the very accurato sights (Scott's) now in the Serriee, there is great likelihood of the guns being damaged also." When the enemy's artillery is protected by natural or artificial cover, common shell must be used. Shrapnel shell is obviously the best projectile to use against infantry or cavalry when exposed or only protected by slight obstacles; but against troops protected by the nature of the ground or substantial corer common shell should be cmployed, as also agrainst buildings or obstacles of solid construction.

One of the most important questions affecting the value of artillery in the field is that of the supply and renewal of ammunition, the arrangements for which should not only be thoroughly considered and laid down, but practised when possible in peace-time.

Breech-loading rifled guns can be more quickly fired than the old M.L. smooth-bore pieces, and when masses of artillery are pusbed carly into action, a very large number of rounds will generally be fired. It is an established principle in the German Servico that " the ammunition in the wagons should first be used and that in the limbers kept as a last reserve;" and Privce Kraft tells us that, in 1870,--" so long as the permissible slowness of the fire rendered it possible to do so, every shell was to be taken direst from the wagon, with which object 3 wagon was posted in rear of No. 2 and another in rear of No. 5."

Anmunition was ullowed to be taken from the gun limbers only in tro cases; to fire tho first shot in a new position before the wagons had come up, and when a rapid fire ras ordered. But as soon as the critical moment had passed, the limbers were as quickly as possible filled up from the wagous." And he says: "I found in the battles of St. Privat and Sedan, when I rode along the line of batteries and looked into the limber boxes they nere full. And when at St. Privat we accompanied the infautry to the assault, the batteries reached the heights which had been captured between St. Privat and Amanvillers, and also the closer position near to St. Prirat, with full limber boxes."

He appears to adrocate posting the wagons in the same line as the guns if there be suffieient space, and contends that they will suffer Iess if so placed than if they were 300 or 400 paces in rear; for he says: "In these days of rifled guns the space of 300 or 400 paces in rear of the batters is more dangerous than a position uear to tho battery and in a line with it, owing to the splinters of the shells which spread about it in all directions. The enems's rifled gans shoot so well that their shells do not go sufficiently wide of the mark to hit the wagons. For the eucrus does not lay on the wagons, but on the guns, which are firing at him," and to prove this ho points ont that-" during the whole of the Battle of St. Prirat no wagon was blown up, but ouly some limbers." I am not quite satisfied on this

1 Which would be done by meanz of common shell. 
point; I think an enemy would firo at wagons as well as guns, and try to blow them up, as guns aro not of mach uso without ammunition, to say nothing of the moral effect and probable killing or wounding of gunners, drivers, and horses by the explosion.

The supply of ammunition in action being so important, tho wagons should follow the guns as closely as prasticable, and the 2nd line of wagons should be within reach. Prince Kraft, citing a case from tho war of 1866 , in which some batteries were separated from their wagons, nud the latter did not come up till the action was over, remarks : "But I learnt one lesson by this: never again to allow the butteries to be separated from all their vagons." Ho goes into detail respecting tho renewal of ammanition in the lines of wagons from the columns, and field depôts, but similar arringements have been laid down for our Service. In peace manceuvres the wagons, under the Captain of the battery, should follow the guns, this Oticer selecting good positions for them as regards supply and shelter; uvfortunately, at the present time many of our batteries havo no wagons.

I pointed out in 1873 that just before the war of 1870 some militarg critics adopted, from Chalons I think, peculiar ideas as to the employment of field artiller'y, one of their axions being-- "Concentrate your fire but not jour guns," but after the war they appened to be under the impression that the Prussians lad discorered new tactics in nassing their guns. Artillery masses had, however, been emplosed by Napolcon, by the Allies against him at Gross-Bcirin and Jueipzig, by the Russians at Warsaw and Inkerman, by ourselves at Waterloo, in India, and the Crimea as far as we were able, although one great opportunity was thrown away, by tho French in 1859 and by the Austrians in 1866. It is strange that the Prussiaus, who were then alicad of the other Porrers in tho reapon and management of their iufautrs in action, should not have observed these cases and changed their artillery tactics accordingly, but as Prince Kraft says, they still udhered to the traditions of $1813-15$ ap to 1866 .

Napolcon's tactics were to commence an action by sending on light troops and opening a desultory canuonado from various points, to make the enemy compromise his whole force and obtain a knowledge of his position. At the decisire moment an orerwhelming fire from $a$. mass of artillery was poured upon a rreak point of the enemy's line, and after it appeared to hare prodaced tho requisite effect, a largo force of infantry, preceded by light troops, advaneed to the attack, nnd a:companied by the light guns up to case shot ranges, cavalry being kept ready to complete any advantage gained. Against breech. loading small-arms and machine-guns artillery could not be sent forward to such ranges without risking annilitation: but there is now no necessity, as rified guus can shoot as well at 1,200 or 1,500 yards as at 300 or 400 yards. Artillery mas hase to firo over the heads of their own troops when advancing to the attack, and our shells should, therefore, be made so that they may not be liable to premature barsting.

It is now generally held that artillery should not be kept in reserve, hence the Germans, and others after them, have changed the term 
rescrve into that of corps artillery; and it is pushed on as far forward as practicable on the march, so that by its fire it mas concenl the morements of the infuntry when coming into action. This might sometimes be hazardous, as pointed out by General Sir E. Hamley in his "Operations of War," 3rd Edition.

It is sometimes said by Omiecrs of other arms that artillery Officers endearour to make a mystery of their arm, and this complaint has been echocd cren by some artillery Officers. I have seen little to justify such a complaint. Tho details of gun and ammunition are rather complicated in these days, but it is hardly necessary for Genernls or other Oficers to master these. All they want is to bnowwhat the fire of guns can do under various circumstances, the spaces batteries cceupy in different foruations, with a general idea of their tactics. To obtain the first it would be wise to give General and Staff, as well as other infantry and caralry Officers, when practicable, the opportunity of visiting Okehampton, Shoebaryness, and other Gunnery Schools. and observe the practice there; and these Officers might make valuable suggestions respecting the positions of targets representing troops and in other matters. ${ }^{\circ}$ The others can be got from the drill book and the morements of artillery at mancurres, if they are directed by General Officers aud Officers commanding batteries, in an intelligent manner.

'The orders issued by II.R.H. the Duke of Cambridge at Aldershot, just before the autumu innworres of 1871 , abolished the old-fashioned notion still held by some Generals and Officers commanding troops"that field artillery should conform to the morcments of the other arms;" and detailed instructions are now laid down in the "Field Artillery Drill Book" as to the position and functions of Officers in action, the Officer commanding the artillery taking his orders as to the object required, from the Gencral or other Officer commanding the tinops. They are worded to secure unity of action with necessary control.

One of the great difficulties we hare as a nation to contend agninst is the occurrence of a number of small wars in rarious parts of the world, agninst enemies of different kinds, some mere sarages, others haring firearms of a sort, others organized and possessing rilled small-arms and artillery, and at the samo time to be prepared to take a part in a war on the Continent; and to take eren a sinall part in such a war, wbere such enormous armies are employed, n great strain on our resources must always be placed. No oue with any knowledge of tho requirements of active warfare will deny that we are very weak in artillers. There is no field artillers for militia or voluntecrs, and but an inadequate amount for our regular Arm5, as I think I can show.

1 I am informed bs Captein G. A. K. Wiscles, R.W., that in Jolgium erers infantry regiment is required to end a $\mathrm{Captain}$ to attend for fourteen dass the nrtillery gun practice, and, as there are ecren of these courses annuslly, each regiment lias seren Captains instructed crery jear. Captain Wiseley adds: "I was assured that this instruction is consilcred most valuable, as cnabling the infantry to appreciate the progress in artillers." 
It is, I understand, the intention of our authorities to have two Army Corps, organized so that with the help of reserres it may be put on a war footing without delay.

Now each Army Corps will require-

\begin{tabular}{|c|c|c|}
\hline & $\underset{\text { battericz. }}{\text { Ficld }}$ & $\begin{array}{c}\text { IIorse } \\
\text { batterics. }\end{array}$ \\
\hline Divisional artillery $\ldots \ldots \ldots \ldots$ & 9 & .. \\
\hline Corns artillery $\ldots \ldots \ldots \ldots \ldots \ldots$ & 2 & 3 \\
\hline Anmunition columns......... & $\overline{7}$ & .. \\
\hline Total ............... & 18 & $\mathbf{3}$ \\
\hline 'I'wo Army Corps............. & 36 & 6 \\
\hline Cavalry dirision............ & $\because$ & 2 \\
\hline Ammunition column $\ldots \ldots \ldots \ldots$ & 1 & $\cdots$ \\
\hline I lines of communication ....... & 2 & $\cdots$ \\
\hline Total batteries ........ & 30 & 8 \\
\hline
\end{tabular}

Fifteen feld batteries are to be converted into ammunition columns, but ns we hare only thirty-eight. field and nine horse artillerg batteries at home, we should be short by one field battery, and have only one battery of horse artillery and the depóts for emergencies and relief.

Now consider the condition of our batteries at home. Until just before I went to Aldershot in 1879, all our field batteries had 6 guns and 6 wagous, with 92 or 84 horses, but some of the wagons were then reduced. Not long after, in some batteries the guns were reduced from 6 to 4, and now there aro 4 horse and 16 field batteries with ouly 4 guns. As a consequence the establishments were reduced, so that they have recently been reaker than they have erer becu sirn? the Crimenu War.

The home establishments are now-

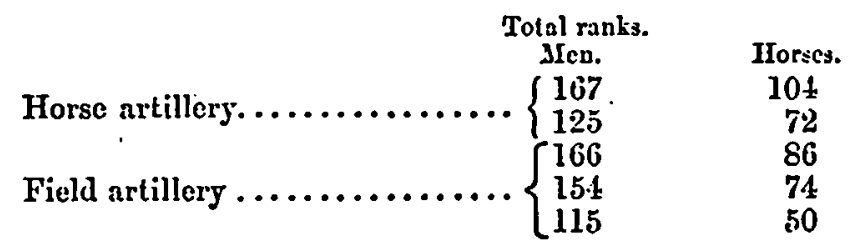

The war establishments are-

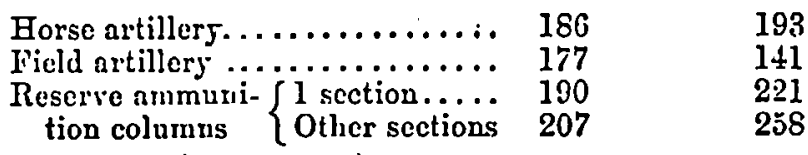

Where are you going to get trained men and horses to make these numbers complete? You have a small reserve of artillersmen, but remember that you will want about one-third more men and horses to make up casualties after a few months' campaigning. The new 
plnn of registering horses in civil employ may give us numbers, but will they be trained to stand fre? And many of them will probably be much "used;" and, besides artillery, tho cavalry, Army Survice Corps, and other troops will require large additions. ${ }^{3}$ Then You have India to provide for, and in the eveut of a war with one of the greatest Europrean Powers, we shonld certainly have to fight there as well as ou the Continent. You may get horses in India, but you must send men there in peace-time, and very large drafts daring a war. Whether jou form more batteries now or hereafter, as sou may be furced to do, all batteries of field artillery should have six guns and sis wagons, which is a mero peace establishment and which would not entail very great cost. I should like to ask what is meant b5 tho heading in the "Detail of an Army Corps" of "Guns-four or six horsed." "Tho Burlin correspoudent of nn Euglish newspaper stated the other day that "in order to enable the German artillery to bo mobilized as rapidly as the French, it is intended completely to horse it in lime of pence, as is already the case in France."

In a paper recently written by Major-General Stothard, late R.E., in Colburn's "United Service Mlagazine," he gires ninety-six guns to a Gerwan Army Corps of 37,179 of all ranks; but some three year's after the War of 1870, the artillery of the Guards Corps and first eleven Army Corps was increased to 102 gaus, as I stated at the time on the authority of our 'Topographical Department. The French have a bigher proportion than the Germans, but it is said that a Bill involsing a rery large expenditure is shortls to be introduced in the Reiclistar to complete the German artillery. In our Army Corps wo liave only $8 t$ guns to $34,9 S 4$ men; 14 machine-guns are added, bat they are not artillery, and if considered necessiry will doubtless be added by forcign Power's to assist the other arms.

We are all aware of the dificulties to be surmounted, both by the military authorities and by the Government, in their attempts to carry out the recomruendations of the former, when these entail the expenditure of mones; but no effort should be spared to open the eyes of the British public to the defeiencies in our military and naval establisliments. It would be folly to attempt to satisfy the ideal wants of certain soldiers and sailors, and some of these are rather apt to treat what should be a sober matter-of-fact question in a gushing or sensatioual manuer; while the British public, upon whom, by our extmordintury method of politics, is derolved the power of consenting to or rejecting proposed measures, was said by one of our greatest authors to be "composed mostly of fools." Without endorsing such a sweeping assertion, it can hardly be denied that the British public is not very eulightened on military questions. I met a commercial gentleman when quartered at Shetticld a fer jears ago, who seriously maintained that it was a great mistake to kecp up any army, and that

1 At Aldershot last autumn four guns of 3 batters of horse artillerg were eyuipped for strvice with a fying column. 'lo make this reduced battery up to the requisite strength, the dratight horses of the remaining tro gung, the whole of the draught horses of another batters, and some of the draught hor'ses of a third batters liad to be taken. 
war could bo carried on most cheaply and successfully by entrasting the management of it to a contractor. Then, lnst jear, in order to obtain eridence on the best methods of training Oflicers for the Arm5, a Parliamentary Committce called an accountant before them, whose opinions on such a subject were worth nothing, and he was questioned by an old artillery Otticer, who should have known something of the matter, the result being, as was doubtless desired, a recommendation to abolish all military colleges and schools us too expensive, and trust to chance training, as was done some century or two ago.

I have no wish to criticize those who aro endearouriug to place the Army on a solid footing, bat there is a tendency to suppose that evcrything has to be commenced afresh. MIuch has been done during the last 30 years, and improrements hare been constantly carried forward, although there was one period of staguation. Manj of those whin worked hard and did most to improve matters have been got rid of, and their successors are not always grateful for advantages already secured. Our armaments have been immensely dereloped; both Officers and men are better educated and trained; the science and practice of gnnnery, musketry, engineering, mining, \&c., Lave made grent strides; short service has been adopted, which has given us a reservo of men; the Volunteer Movement Las becn established; the transport, supply, and other services havo been placed on a recognized fuoting; antumn manoourres and minor tactics have been practised; and a number of small wars have kept alive the military spirit, and, to somo extent, tested our deficiencics. As for the artillery, which has been reorganized sereral times since the Crimean War, an important step was taken shortly after, in placing field balteries on a proper footing by making them permanent, and giving them a proportion of drivers, and their mobility was afterwards increased by mounting tho gunners on the limbers, axletree-sents, and wagons : but fer would say that the present incornprehensible organization of the regiment is satisfactury.

I trust that no one will suppose that in what I have said I have made any attack on so distiuguished a soldier as I Lord Wolseley. I have certainly contended agaiust one of his opinions, which I anil many others consider unsound, and my reason for doing so is, that his opiuions naturally carry so much weight from his abilities and position. I have, however, confidence that Lord Wolseley is not above modifying his opinion if facts show that change is necessary; and I hope that what I have said, together with remarks made by otbers in the discussion, will appear to him sufficient to induce him to reconsider his low estimate of the destructive power of artillery. What, howerer, I particularly wish to point ont is, that we should ascertain practically what, we can do with our various weapous, and then snit our tactics to their special purposes. Shrapnel shell, common shell with high explosive bursting charges, quick-firing and machine-guns, and inngazine rifled muskets all clain to do great things, but practice under service conditions call alono decide their relative values and proper positions. Having ascertained these, our Gencrals and the troops under them mily go into action with the confidence of being able to employ them to the best advantage. IVhat 
the Germnns accomplished in four years, between 1866 and 1870, by the establishment of a school of gunnery, and by changing their obsolete artillery tactics to meet new conditions, shows clearly what can be done in pence-timo to prepare for success in wur.

T'bero is another thing I wish to say before sitting down. Both before and after the Crimean War, pamphlets were written, ono by a Russian General and the other by a British Colonel, to show that artillery had become the principal arm. I have had no intention of makingr any such claim, aud repudiate the idea, as Colonel C. Brackenburs did at Aldershot, nlthough some of those who spoke after the lecture thought that he had attempted to show that artillery conld always annililute any troops oppused to them. 'The bulk of the Army must be infantry; no position can be taken or kept without it, and infuntry must, therefore, be the principnl arm; unless, among those hight explosires we hear so much abont, we can discorer the tril of the Coming Race, when no troops of ans kind would bo required. All I claim for artillery at the present time is, that if properly equipped, organized, trained, and emploged, it can give very great assistance to the other arms; if-even well organized and cquipped-it be badly trained and handled in action, these other arms will suffer great losses in endeavouring to accomplish their objects, besides ruming tho risk of defeat and disaster.

Iiesulls of Practice at Olichampton in 1883 with the I2-pr. B.I. Gun.

(1.) Target, $-A$ singlo line of 70 standing dummies, about 1 yard per dummy.

Range varying from 1,500 to 1,750 yards.

4 common shell to find the ringe, and then a group of shrapnel frow each battery.

\begin{tabular}{|c|c|c|c|c|}
\hline Batters.' & $\begin{array}{l}\text { Number of } \\
\text { slirapnel. }\end{array}$ & $\begin{array}{c}\text { Number of } \\
\text { hits. }\end{array}$ & $\begin{array}{l}\text { Number of } \\
\text { snen lit. }\end{array}$ & Remarks. \\
\hline $\begin{array}{l}1 \\
2 \\
3 \\
4 \\
5 \\
6\end{array}$ & $\begin{array}{r}14 \\
14 \\
14 \\
14 \\
9 \\
11\end{array}$ & $\begin{array}{r}131 \\
66 \\
26 \\
31 \\
72 \\
59\end{array}$ & $\begin{array}{l}22 \\
16 \\
20 \\
22 \\
39 \\
25\end{array}$ & $\begin{array}{l}\text { Fired with percussion } \\
\text { fuzes. }\end{array}$ \\
\hline
\end{tabular}

(2.) Target, -3 rows of standing dummies, 35 dummies in each row, 10 yards between tho rows :-

1 The numbers in this column arc put to distinguish tho groups of shell fired from different batterics of horso and field artillers, the letters and numbers of which aro purposely omitted. 
35 Jards.

응.

Range raried from 1,950 to 2,100 yards with different batteries.

4 common shell to find range, and then a group of 14 shrapnel from each battery.

$\left.\begin{array}{c|c|c|c}\hline \text { Batters. } & \begin{array}{c}\text { Number of } \\ \text { bits. }\end{array} & \begin{array}{c}\text { Number of } \\ \text { wen hit. }\end{array} & \text { Rewarks. } \\ \hline 1 & 83 & 46 \\ 2 & 110 & 55 \\ 3 & 116 & 62 \\ 4 & 117 & 53 \\ 5 & 143 & 67 \\ 6 & 111 & 30 \\ 7 & 140 & 34 \\ 8 & 151 & 43 \\ 9 & 61 & 40 \\ 10 & 330 & 63 \\ 11 & 145 & 39 \\ 12 & 90 & 29\end{array}\right\}$

(3.) Target,-Scattered infantry, retreating across a ravine, represented by 45 standing darnmies scattered about in twos and threes.

Range about 1,000 yards.

4 commou shell to find range, then 6 shrapnel.

\begin{tabular}{c|c|c|c}
\hline Batters. & $\begin{array}{c}\text { Number of } \\
\text { hits. }\end{array}$ & $\begin{array}{c}\text { Number of } \\
\text { men hit. }\end{array}$ & Remarks. \\
\hline 1 & 50 & 25 & \\
2 & 23 & 17 & \\
\hline
\end{tabular}

(4.) 'Taryet, - An irregular lino of standing dummies, towards which the 3 batteries composing each detachment galloped in liue about 300 fards down bill over rough heather, and then came into action at ranges varying from 300 to 450 yards. Fach battery fired 15 rounds of case shot. The line of dummies was divided into 3 groups to allow the result of cach battery's practico being distinguished. 


\begin{tabular}{c|c|c|c|c}
\hline Batters. & $\begin{array}{c}\text { Number of } \\
\text { dummics } \\
\text { fired at. }\end{array}$ & $\begin{array}{c}\text { Number of } \\
\text { lits. }\end{array}$ & $\begin{array}{c}\text { Number of } \\
\text { nou hit. }\end{array}$ & Remarks. \\
\hline 1 & 27 & 127 & 25 \\
2 & 25 & 201 & 25 \\
3 & 20 & 97 & 20 \\
4 & 20 & 27 & 15 \\
5 & 20 & 63 & 19 & \\
6 & 20 & 45 & 18 & \\
\hline
\end{tabular}

(5.) Target,- Battery in action represented by 6 dammy guns, and detachments of 5 dummies to each, making $30 \mathrm{men}$. The limbers were represented by canvas screens, which did not give trustworthy results, but on service the limbers might often be under cover.

Range about 1,900 jards.

12 rounds of common ${ }^{1}$ and 12 of shrapuel shells were fired from cach battery.

\begin{tabular}{|c|c|c|c|}
\hline Battery. & $\begin{array}{c}\text { Number of } \\
\text { hits. }\end{array}$ & $\begin{array}{l}\text { Number of } \\
\text { men hit. }\end{array}$ & Remarks. \\
\hline $\begin{array}{l}1 \\
2 \\
3 \\
4 \\
5 \\
6 \\
7 \\
8 \\
8\end{array}$ & $\begin{array}{l}31 \\
35 \\
30 \\
13 \\
50 \\
56 \\
15 \\
20 \\
14\end{array}$ & $\begin{array}{l}10 \\
14 \\
17 \\
10 \\
16 \\
18 \\
10 \\
12 \\
10\end{array}$ & $\begin{array}{l}1 \text { gun detrichment blown to pieces. } \\
1 \text { gun disabled. } \\
\text { " " } " \text { and } 1 \text { dummy } \\
\text { blomn to pieces. } \\
1 \text { gun disabled. }\end{array}$ \\
\hline
\end{tabular}

(6.) Target, -30 standing dummies in line.

Kange about 200 jards.

12 shrapnel shell from each batterg, with fuzes set to burst at the muzzle.

A good instance of the destructive power of shrapuel practice was the following, the results of a group of 10 shrapnel fired at Okehampton last ycar.

1 The stecl common shell for the 12-pr. is so tough that it simply tears open, and is practically uscless agninst troops, though its large bursting charge makes it rery effectire against carthrorks, \&c. 


\begin{tabular}{c|c|c|c}
\hline Bntters. & $\begin{array}{c}\text { Niumber of } \\
\text { hits. }\end{array}$ & $\begin{array}{c}\text { Number of } \\
\text { wen hit. }\end{array}$ & Remarks. \\
\hline 1 & 29 & 19 & Result not good. \\
2 & 13 & 6 & \\
3 & 18 & 8 & \\
\hline
\end{tabular}

Target,-A subdivision. Gun and limber, the latter represented by a canras $6^{\prime} \times 6^{\prime}$ screen; the detachment and horses being represented by 13 dammics, those for the latter not being so large as horses.

Kauge 2,650 yards.

Results. 147 hits on horses and detachment.
$60 "$ the gun.
Total... 2 222 hits.

The instances of practice at various objects giren above haro been taken from the records of practice carried out at Okehampton by tho batteries sent there last year. Tho practice was arranged and the results collected by Colonel MIurdoch, R.H.A., who commanded the camp, with the assistance of his orderly Officer, Lientenant J. Headlam, R.Il.A. The number of shell fired in each group was small, the object was to get as much instruction as possible out of the ammnnition allowed for practice. The ranges were never measured, but found by the range-finder and trial shells; the ground is rough, with considerable differences of lerel between that on which gun and target respectively stand, and the wenther was generally bad.

Colonel F. MIAREusr, D.A.G., R.A.: The rery interesting paper which has been read by my fricnd General Orea is what we should haro expected rould hare cowe from his pen, as we know he bas studicd the subject for eo many years. The beading of it is, "The Value of Artillers in the Ficld;" but it seenis to we it has rather become a historical sketch of the field artillery of this comintry up to the present das. He las trarersed a rerg great deal of ground; I do not intend to follorr bim orer the whole of it, but there are a few remarks that I wish to make. He has alluded to the mobility of the artillery, which is most importint in the ficld, but he lins not mentioned what he considers ehould be the proper calibre of guus for the horse and field artillery. He has, howerer, mentioned a t-pounder as proposed for horse artillery. I presume he alluded to u quick.firing gun, because it follows wliat he has mentioned regarding quick-firing guns. In that I think he has made a mistake. Ilr. Fordenfelt will correct me if I am wrong, but I beliere it should be the 8.pounder quick-firing gun which is going to be tried this sear at Oleliampton. He also, iu alluding to shell fire, said lie thought there ought to be certain batterics, attached to an army corps, of ficld howitzers. We hare also this jear brouglit forward, and are going to try at Okeliampton, some ficld howitzcrs,

1 The unsatisfactory result was due to the shortuess of the range, sowe of the shells bursting onls just before reaching the target. Ctood results would doubtle have becn obtuined at 300 or 400 jards range. 
4-25-inch borc, which will be tested against the 20-pounder guns which we tricd last year, both rcry powerful guns. General Owen was quite right in sibjing that ineasures bare been taken to try and remedy the immense recoil giren to high velocity guns. We are trsing a carriage now with recoil buffers : they hare been tried alrealy with the 20-pounder, and also on the field howitzer carriage. Alluding to the pract ice of picking up ranges, it is a rers important point, and I think our instruction is becping pare with the improventent of the gut. Wo draw up our rules erery ycar, and they are resised from experience gained the jear beforc. I must sas I sbould like to sce sereral Onteers of other brinches of the serrice go down there and sec the shooting; I think they would then appreciate the fire of artillery; and they would ece that our artillery is not behindhand in the instruction to the Officers and men. General Owen alluded to certain Olficers thinking that the artillery inade a mystery of their arm, but he thinks that this idea is now exploded. I think it is so. I can assure jou of this fact. Last year I went to Okchanpton in company with two Qeneral Officers of infantry and screral others, one a caralry. man. I belicre thes camo awas rers much impressed with whit thes liad seen of the fire of artillery. I may also mention, although it has nothing to do with this paper, that a General Olicer of caralry, who commands a district in England, attended a course of gunnery at Shoeburgness last year. I think this prores that the artillery ecrrice is not bept in the dark at all, but that we as artillerymen are only too glid to sec other Oflicers of different branches of the Service take up tho question, and come and sec what artillers can do. I rather wish-but perhaps it was a little outside the limits of the lecture-that General Owen had alluded to the selection of positions for guns in action. 'This is a question which has cropped up latels, and is rather important, and has been under consideration; and with refercace to the supply of anmunition, where the limbers should be placed. Of course we bare in these cases been obliged to pick our knowledge from experience gained in foreign countries, but it would be a very difficult thing to draw a land and fats line as to where the position of limbers should be for the supply of ammunition; it depends so much upon circumstances, upon the vature of the ground, upon when you aro going into uction, whether you are engaging an cnemy who alreads holds tho ground, or whether you have the adruntage of selecting the position and naiting for him to attack. We hare now been drawing up a new Mranual of Field Artillery Exercises, in which we hare considered all theso questions, aud also that one of keping the limbers away when they come into action, and bringing up some of the wagons, so that when an udrauce is necessary jou bare your limber full of anniutition und ready for the work. I see, looking at the table before me, that General Owen has talked about the number of our batteries, and how inadequate they are for the defence of the country. I am happy to 805 thit that tablo shortly will not prore quite correct. IIe puts fftcen batteries with the ammunition columns. Arrangenents are now in preparation to grodually work these out, o that thero will not be a necessity to convert field batteries into aumunition columns. With reference to finding men and horses in these large numbers, wo find the rescric is sufficient to provide men for the first army corps to fill them up to war strength. Then we have our ammunition columns arranged, and bave no longer to convert batteries for that purpose, we shall find that we have a reserro of some fourtecn batteries to drar upon after proriding two army corps cons. plete. Fo ammunition columns could be kept up in peace-time: I think that nill stand to reason to erersone, for what will be their duties? You would haro a lot of men and horses, maintained at great expense, practically without employment. After that we come to the militia and rolunteers. General Owen says they hare no field artillery. No, they have not ; but they hare a rery large force now of guns of position. They hare 10.1 10-pounders, 23 20-pounders, and 132 16.pounders, or 264 guns in all; and 252 of them are actually in the hands of the rolunteers. Thes are horsed in different wags, some with farm horses and harness, and some of them hare applied and hare reccired permission to purchino artillery harness, and drire in the samo was as tho Kosal Artillers. I hare only Inentioned these few points, because $I$ am in a position to inform General $O$ wen how they stand.

Colonel Losspars HaIE: I rise at this early period of the discussion because I 
hare to go amay inmediately and superintend the firing of leaden artillery, and the morements of leaden eoldiers clserrlicre. I wish to express the hope that eitlier the lecturer or some artillers Olicer will gire us some information upon one of the most important parts of the duties of artillery in the ficld-the value of field artillers, as it is at present, against localities, in which $I$ of course include substantially built villages. Nobody has a firmer belief in artillery that I lare myself, but what I should like this afternoon would be that some artillery Oficer should gire us reliablo information on the subject, and I trust, it will be of a reassuring clancter. Supposing a battery: came into action in IIyde Park, and fired away at houecs of the charucter of those built in Park Lane, what eflect nould tliat batters produce upon those houses? Mrs friend Colonel Brackenburs has lately brought this subject of loc:alitics before the public, und lie is not a more arderit belierer than $I$ au in the part that the defence of localities will take in any future war. I differ from Colonel IBrackenbury, perhnps, in his view of the shelter trench part of it, but at the eane timo I firmly beliere that the points that will be held on a battle-field will be strongly defended buildings and rilluges, and garrisons will nerer be turned out of these unless the artillery can help to do it, und do it effectively. I hare been Jately studying the details of the defence of the position of Failly-Noisscrille, and, so fur as I sce, the effect of our artillery at present upon localities and upon garrisons of localities will be very much the sane as the cffect of the French artillery upon the Prussian garrison at Servingy. The French artillery fircl shells, and set fire to the village in a few places, but with regard to the garrison, they did not care two pins about it. What we should like to know is, whether, with the artillery missiles which ne possess at prescnt, wo can with a small force of artillery render a locality untenable. Supposing that localits is not made of paltry little houses, how far well-built houses can be rendered untenable cither by the fire of common shall or shrapncl. I ain quite aware that if you get cuough guns you can knock uny rillage to pices if jou lare time to do it and have enough gun like the serenty-ciglit which battered Foisseville on septeniber 1, 1870; but we liare no authentic information as to the actual effect of the present shell, not the shell of the future, which is to be inrented, with high exploziro compounds, and so forth, but merely tho shells of lo.day. Can artillers Oficers here undertiale to turn a gurrison out by firing conmon shell and slirapucl, prorided the garrison are placed according to common sense und properly under corer? That is tho point on which I hope artillery Officers will gire us information this erening.

Colonel JICrice, R.A.: I propose to rcstrict myself to one particular point of this most raluable and interesting lecture, that is, as to the question of moral effect as connected with the material effect of artillery, and the references which hare been made to the mode in which that subject has been dealt with by three friends of ny own in the other arms of the Scrvice, the late Colonel Home, R. F., General Clery, and Iord Wolscley. I, for one, certainls belicro nost surely both in the material effect which is produced by artillers, and in the enormously enhaned material effect which will be produced by artillery with our improred sights and our improred guns. But for all that, I cannot admit that it is a disparngement to our arm of the Service to sas that its great feature is the extruorninary moral effect which it produces. Take any other arm of the Service: tahe the infantry. We are all agreed that if it were possible for the infantry habitually to fre rolless instead of engaring in indiridual shooting, it would be most desirable that they should do so, and it is onls because rolleys cannot as $\Omega$ rule be fred in action, that ke are unfortunately obliged to abandon rolless, and to restrict ourselres chieily to independent firing. Now the enormous difference between rolles firing and independeat firing is eimply a difference in moral effect. The whole of that marrellous stors, which has been told again and agian bj French writers, eren better than by our own listorians, of the euccessire rictories of our troops in the Peninsula aguinst French troops has been acknowledged again and again to prore tho moral effect produced bs infantrs fire delivered suddenls and at a giren moment. Therefore it ocems to me it nuglit not to bo looked upon as a diaparagement of the efliciency for rictory winning purposes of the artillery to say that the moral effect produced by artillerg fire is greater in proportion than the material effect which it also produces. 
The reason why that great moral effect is produced is, I think, a rery simple one: it is preciscly that you get out of the destruction which is produced by artillery just that effect which you would try to get, if you could, from the euployment of infantry. The blow when it is struck has the sudden taking effect of a rolley. The shell when it bursts effectively at all produces an appalling and tremendous effect on one spot and at a giren moment. It is a rery scrious thing, as General Oren has said in his lecture, to see, as 1 hare done, a couple of loorses and men struck orer by $\mathfrak{a}$ single shell; it is a thing that produces an immense effect upon the minds of the men who witness it at the time. And, as it seems to me, the wliole use of the arm, and its proper tactics, are determined bs realizing thut it is this moral effect which, if we are to win rictory, we must cnhance in every way. As far as I have observed myself, and I hare found my observation confirmed bs people who have seen far mure effectire artillers fre than $I$ hare, what continually happens uncter the fire of artillery is this: those who nre exposed to it for the first time fully realize that a shell carries with it the possibilits of that tremendous destructiro effect of which I hare epoken, and as soon as shells begin to hurtle through the air the first few rounds tend to produce an enormous moral effect. But after a little time men observe that there nre, a great many shells which produce no material cffect, you hare plenty of time to watch them, to ece them down, and you sce that they produce no effect, and this gocs on for a long time, before the next destruction is produced by an effective shell. It is almost alwajs soon after the beginning of artillery fire that this loss of moral effect is apt to oceur, becules artillery usually berins at long ranges, and because the range has not been quite so accurately found as it is later in the action. Not being at that time in danger of infantry attack the troops under artillery fre can then better than afterwards taice corer from it. For various reasons of that bind the early period of artillery fire rather tends, unless it is a rery concentrated artillery fire, to undo ito own moral effect. Fou hure plenty of time to watch erery shot with artillery as you hisre not plenty of time to watch erers shot that is fired from the immense nass of unained ineffective infantry fire. You cannot count bullets coming through the air, but where you sce shells, as jou may do, coming and cxploding liarmlessly, it tends rery greatly to discount the moral efrect of artillers. For niy purt I havo always beliercd, and I think I am right in that opinion, and I hase geverally confirmed myself by comparing notes with other peuple, that the enormous importance to us of concentrated artillery simply depends on the great moral cifcet which is produced by the concentration. Becuse if you have an enormous number of guus operating upon a single poiut, and th. shells bursting in the air all nbout jou, there is no. time to male the calculation as to the ma!erial effect between ono shell that does strike and spread ruin and the next that does so; and, therefore, sceing that there is continually a certain amount of destructire ellect, and the shells are continually coming, the sbells that don't strike tend to enbance the moral effect instead of redueing it as they do when there ure long intervals without effect. Therefore it accuns to we of the greatcst importanec that we should recognize both in the use of artillers and with regard to the power and effect of the arm, that it should bo so emplojed as to produce that which is the object of all war, which is in all cases and in relation to all arms of the Serrico the grand thing at which ne aim, which, a Napolcon eaid, counts for nine parts in ten ia battle, the production of moral cffect. I belicre, njself, that the rery great increase which we are making to the future material effect of the gun will rery greatly cnhance that moral elfect, and that ang future successes will be due nol merily to the material loss which will be occ:ssioned, but because of the enhanced moral effect which the artillery will on that account produce. I want to turn to another question in convection with that, and that is the relation of artillery Offrers towards tle other arms of the Serrice, in the riew which they would wish them to tuke of their arm. I do not for one moment beliere thal there is the smallest fear that Onicers of other arms will underrate the effect which our own particular nrw of the Serrice, the artillery, will produce in the next camplaign. But supposing you were in command of a body of caralrs, dealing with a body of infantry, would uot you wish to inspiro that caralry with a fecling that jou intended so to lead them aguinst the infantry against which they picre going to be engiged, thut you would nerer allow them to do angthing 
else than to go forward to victorg, that nercr should they hare to como disastrously under the killing porrer of infantry, but that, taking adrantage of the rapilits of sour morements, and the fucility of sour munoeurring porer, with jour knowledgo of ground and your skill in using it, and your power of striking round the flanks of the enemy, jou would always gain the rictory no matter what weapon might be in their hands? Aud, on the other hand, if you were in command of a body of infontry, resisting that rery caralry, rould uot you wish to inspire that body of infantry with the fecling that if they are ouly able to beep command of themselres and keep steady with their respons, they will most asouredly win? When you come to criticize thesc books which are written for the inetruction of caralry and infintry Officers, it is not for the adrantage of the artillery any more than for the adrantage of any other arm of the Scrrice that the infuntry and caralry who are going to co-operate with us should feur the guns that are to be used against them by one of the enemies of England. It is not against them that we are going to use our guns, thes are going to join us in fighting agninst the guns of quitc another Joner, and I am perfectly certain that to take the specifie instances of which Colonel Hole has spoken, the fecling which actuated wy friend Colonel Ifome in spenking mainly for caralry and for the inf:antry which must bc, of course, the most important arm of the Serrice, ho had this object iu riew, and had no object whaterer in dis. paraging the artillery. As a matter of fact, I maj sas Colonel llome's unfortunately premature death, which is one of the greatest losses the Serrice has had in my time, has deprired us of the enormous adrantage of the sucecseire rerisions which his book would hare receired bad he lired, and I cun answer for it from my own personal knowledgo that that book as it stands does not in the smallest denree represent his final riers or anything that be would now be satisfied with, had he had the means of carrying out the rerision which he would hare wislied to gire to it; thercfore, I mas admit that there are certain things in it which I should well wish out of it, valunble ns it is and instinct with his peculiar soldierly genius. In relation to the particular statenuent wade ns to General Clery's book ou "Ifinor Tactics," it is simply a question of fact. There is the book. It is ore rery familiar to most Officers, and I can only sas I have this afterncon carefully gone orer the chapter on the relation of the three arms of the Serrice, which is the one in which all theso qucstions of artillery are mainly or entirely dealt with, und there is not a singlo illustration, a single instance, taken except nut of the war of 18\%0. Colonel Ifale has long since abolished for us all history prior to the war of 1870. I want to know whether all illustrations from the 1870 campaign are also to be abolished I quite admit that we are going to hare an enormous increase in tho power of artillery in the future, but, for the purpose of a tert-book, it is impossible to dcal with other than the cxperience of war, and I do not think the attack is quite a fair one upon a test-book which is prepared for a certain specific purposc, and which nust deal ritl the actual erents of war, and not with the opinions which we naturally form as to the fut ure of our onn arm. Lastly, I should like to say one word about what has bcen said in relation to Lord Wolseley's "Pocket Book." That book was originilly written when he was a Colonel of infantry in Canada, and the rers passage which is quoted is directed to the particular effect which ought to be produced upon the winds of iufantrs who mas bare to facc artillery in the feld. I confess niyself I should be rery sorry to do other than inspire our infantry with the utmost confidence, and as I lave urged the effect of artillery is unquestion:abl, from it 3 nat ure, to produce a moral ellect out of all proportion to its muterial effect, great as that material effect is, therefore, most assuredly, I should like as far as I possibly can, spcaking us an artillery Officer, to discount for all our infantry Oflicers who lare to come into action against artillery, the moral effect which the artillery of tho cnems will quite sufliciently. produce upon them by its material effect. I have no doube that that was the motive with which that particular passage was introluced. A passage which originally was written by a Colonel of infuntrs, spealing especially to his orrn arm of the Serrice, has through suecessire editions becone the work of the dijutant-Geueral of the Arms, speabiug to the whole Army. In that position I still sas that the most important duty of a unau who wants to carry forward the A rimy as a whole to victory is to discount us far as pussible beforehand the tremendons moril effect which will be assuredly liable to be produced by the striking and 
dramatically appalling effect produced by hostile artillers. There is no fear that ho will shake the confidence of artillery Oflicers in their own arm. I can say positirely that no man has more confidence in the artillery than I.ord Wolseles. If $I$ may renture to $\mathrm{s}$ s so, in a mised assembly of Oficers like this, not once, but again und again Lord W'olseley has eaid to me, as he has said to others, "I do not sas this becausc jou are an ortiliery Onicer, but becultsc I find it so-the artillers Oflicers are the best Oflicers of the Army." Therefore I mas assure jou that it is not from come special prejudice ngainst the artillery that Lord Wolscles lins spoken in the way in which he hus done in the " P'ocket Book." Ife has tho most complete confinence that notling that he snys will in the smallest degree shake the confiderce of the artillery in their arm of tise Serrice. The rery best effect that could be produced upon the rest of the Army is to tell them to go forward aguinst the artillers of the enemr with erery possible confidence, and to discount as far as possible, by statisties or othicrwisc, the tremendous moml cffect which the immediate and striking material effect of artillers tends to produce?

General Sir Grosd Grairasi, v.C.: Not being an artillersunan I renture to add my testimony to Colonel Hule's as to the ralue of artillers in the ficld. I had not the adrantage of being present at Colonel IIale's lecture at Aldershot, but I haro hearl him lecture at this theatre on a similar topic, and I think, on that occasion, he somewhat successfully demolished mucl of the statistics that are relied on to prore the ineficacy of artillers in the field. I am only sorry that he had to leare us so soon this afternoon, and did not rc-enter on that subject. I can state wy belief, not only in the ralue of artillery, but that our artillery is the finest in the world as a service, and $I$ ain happy to hear that confirmed by so high an authority ns Lord Wolseley, as quoted by Colonel Jinurice just now, as regards the artillery Offeera. There is one point I should like to refer to, as coming from an Onicer of General Oren's great cxperience and authority, and that is his opinion of quick.

1 In speaking I omitted to dram attention to an obrious wisunderstanding of some iniportance as to the phrase used on p. 121 of the last edition of the "Soldier's Pocket 3ook." "In prerious editions of this 'I'ocket Book' I hare laid stress upon the fact that the effect of artillers fire is more moral than actual, and I trust that these figures will make the Armr, especially the infantry, fully recognize the trutl of that assertion, and put a stop to the ery for more guns which one still hears occasionally." The last phrase has I find been eupposed to injply that Isord Wolscles is conteut with the fact that wo have hitherto had no guns for the home Army, rolunteers, and inilitia at all. This is purels a misreading of the text, which simply objcets to an increase in the proportion of guns in the field bejond the 3.75 per 1,000 men which Lord Wolscley has elsewhere spoken of $\mathrm{n}$ a marimum. As a matter of fact no one has represcnted our deliciencies in respect of the home Army more strongly than Lord Wolecles. I was, when Coloncl Scott came iu, on the point of siring that we also ore cntirely to Lord Wolseles what all artillery Officers now recognize as at letst one of the most important inprovements in our time of the artillery armScott's sights. I may add that from the point of riew maintained in my spech, no eridence subsequent to the War of 1870 , 13 to the future materinl effect of artillers in war, affects the argument. If the rictors winning effect of artillers due to its moral effect was so great, as we know it to hare been at Sedan, where the Euperor declared that he surrendered to the artillers, the vhole question is whether in that war the matcrial effect was such as with any other arm would hare produced that moral effect. If not, for hearen's sale let our infantry and caralry bnow and understand that fact. They will necd all their bnewledge of it, and all their national phlegm to resist the moral effect of the appalling material effect which artillers will procluce in the next war. The technical phrise that it is the duty of artillers "to preparc the way for attack" means that it is their duts so to sliake the nerres of the defenders that they may succumb to attack. Ought artillery Oncers to wish that their own Arms should be prepired beforchand to succunb by cramming down tbeir throats all possible eridence as to the reality of the danger, or should they wish rather that the $d r w y$ should buow that, bad as it looks and is, it looks worsc than it is. 
firing guns. ITe sajs: "I cannot sec how thes could be used to anj cxtent in tlie ficld. ns they require to be fired continuously from the same position without recoil." I should be glad to hear from General Owen why the fuct of their being fircl continuously, without recoil, should make them of no use, or of little tise in the field. I should hare thought, on the contrars, it would hare chlianced their ralue in the ficld. Cenerul Oren sajs: "I hore often thought that our ficld carrioges might be improred by haring recoil slides, or some arrangement. for lessening recoil. If the recoil could be prerented, both the accurncy and rapidity of firing would be increased, the labour of running up mould be aroided," and so on. It appears to me that General Oren there recognizes the ralue of non-recoil carriages, and, therefore, I cannot quite understand the first part of the paragraph. General Owen also says, "They might, ns their adrocites say, fire a greater weight of metal in a giren time; but I think that is a fallacious comparison." That is with reference to the small calibre of the 6-pounder gun. Colonel Markham has alreals obscred it is an 8.pounder gun, but I wish to inquire why the nbore should be called a "fallarious comparicon." I stould have thought that for a light gun to be able to fire a greatcr weight of metal in a giren tiue than a licars gun would be an enormous adrantage. Referring to the subsequent remark of tho lecturer on the great importance of lightiness and the long marches performed by artillers quoted from Prince Iraft, the cnormous importance is obvious of liaving light guns, and ereryone who lsas seen any serrice will reconnize that as a most important factor in the gun. Those who wero in Erypt will remember that the 13-pounder we had there, though a most miluable gun, was too heary for the sand of the desert, and could not be brought out and made full use of on account of it 3 wcight. \& light gun that will throw an cqual meinht of metal and produce a greater intensity of fire must hare an enormous adrantage orer the lieary gun, eren although each indiridual round maj not produce the same effect. The 6 -pounder referred to mas te fired at the rate of 40 rounds a minute, which is a very great intensity of fire, and it is a rery light gun. Iieference is made to the IIasim ns being merely a machine-gun. Of course General Owen is aware that there is a light sleell-firing Maxim, a 37-millinetre gun, that fires 300 , and has fired 400 rounds a minute. There jou bare a light machine-gun where you hare the adrantage of eceing the range, and, therefore, there would no longer be the same objection made to it that there is to other machine-guns where you could not obserre the effect at a long range like 3,000 sards. The reference to the mitrailleuse is, I think, somewhat nisleading at the present daj. At that time the tactics of machine-guns were not understood, they werc cmployed against artillers at long ranges, und, of course, cntirels failed. It is rers remarkable that thes ghould hare been able to hold their orn against artillery on any occasion, as stated by the lecturer, as it is not intended to use machinc-guns ag;inst artillers at long ranges; in fact, they should replace infuntry, as they may replyce long-range infuntry fire, but can nerer be iutended to replace nrtillery fire. There is one point on rhich I quite agree with General Owen, with reference to the quick-firing guns, that, great care would hare to be exercised to prereut the quick fring being inlulged in too often or 100 long a time, in consequence of the running out of ammunition. That is perfectly true, and the same objection applied to the derclopment of the muzle-losding rille into the breech-londer, and replacing the brecel-londer by a magazine rifle. It is a question of fire discipline und training. I think with our artillers we hare less to fear from lack of fire discipline than me hare witb our infantry; the training is higher, and there is not the same difficulty in restraining a gun detachment as there is in restraining infantry in action. It is a matter of nerre, and a gun has no nerres. In my humble opinion all these new introductions are an adrantage to us who, as a nation; I beliere hare better nerres than most other nations. Our men want nothing but training, and the better dereloped weapon put in their liands will ho turned to better account by the British soldier tlian by the soldiers of more escitable nations, sinec the greater control is required orer the nerres for the arms of the present day. So that the objection to quick-firing guns, that thes will tend to raste of ammunition, I think does not apply, assuming, as the lecturer docs, that thes will be used on both sides, which will always be to our adrantage. This leads to the question of the aupply of cnmunition-one of the most im. 
portant questions of the daj. I do not know that the lecturer has attempted to solre it, but lie lias mentioned sorcral very inportant points on which I sliall be rers glid to hear the opinions of artillery Ólicers. Thes hitro alreisdy been referred to to some cstent in regard to placing the wagons in line, and to taking nothing out of the limbers before cunptying the warons. I feel rers much reassured by the rennarks made bs tho Deputy dijutant-General of Royal Artillery. It is a great relicf to us to know that so nucli is being clone to improro tho organization of the Rosal Artillery, more especially with referenco to wliat ho has said as to the ammunition columns.

Captain F. G. Stoxz: I onls nish to male a rers few renarks, first with regard to what General Owen said with refereuec to placing the bursting ebarge of the ehrapnel in the head instcial of in the base. To the best of my belief the object, or at all ercints the rcsult, of placing the bursting charge in the he:ad of the shrapnel, is not principnlly to sccure a ferr additional bullets, but to ensure the quicler ignition of the bursting chisrge, the result being that it has become possible to use percussion shripnel with remarkably good effect, in fact with equally good effect as time shrupnel up to ranges of about 2,000 sarls on ordinary ground. 'This, I think, is $n$ most cnormous gain in the power of artillers fire, and it is not by ans means mercly a question of haring a fes moro bullets in the slivipnel. With regand to the bad esccution done by the mitrailleuse in the war of 1870 , in the first place it was due to the funt of the weapon being extremely clums5, and secondly, because the Olficers and men did not understand technically or tactically the nature of their weapou. With regard to Major IIutton's remark at Aldershot, which General Owen has quoted, referring to the Nordenfelt machine-gun in Foypt, that their firing was rery erratic, Major Irutton pointed out the reason for the indifferent practice by eaying that thes wero not firing from a level platform. Of conrsc nu gun, whether a 40 -pounder gun firing sliell or a machine-gun firing bullets, would be espected to fre correctly unless its whels were on a lerel platform or a compensating sight was used. I venture to think the objection is not to the gun in that case, but rather to the ulter absecce of training which appeured in tho gun detachment. It is mero A $B C$ to nns recruit in the artillers that the whecls must be on the same lerel in order to shoot uccurately, and that if the platform be nut lerel, compensition nust be giren by means of the sights; unless men are properly trained in the uso of their gun jou cannot expect the gun to work of jtsclf.

Captisin Sictyarstr, R.Î.4.: Geneml Owen noked me n few days ago to gire a few esamples of the effect of artillers practice at Okehampton. In 1837, with tho two 20-pounders which I cominanded there, wic fired a quarter of an hour at a range of 2,100 garils at targets to represent a regiment of caralry in quarter colimn, aud we pat 2,000 bullets into tlie targets. Four guns afterwards, 1 believe, put from 3,000 to 4,000 bullets into the earne targets. With regard to what Colonel IInle s:aid as to the destructire effect of shell, I mas mention the effect of firing with a 20-pounder common hell with a percussion fuze on the block-houso dowe there was wonderful. The block-house wis congtructed of two rows of timber from 6 to 8 inches in dianeter with from 6 to 7 feet of eath between. Tho first shell from the 20 -pounder pissed througl the first row of timber, burst in the carth inside, and completely opened the eccond stockalc behind the timber, inaking an cnormous breach in tlie block-Louse. 'Therc was somctling more than moril effect in that, na jou call inagine. Then, agitin, as to what Sir Gerald Grahasu said sbout our guns being too heary. 'The lighter mature of guns, I think the 13-ponnder and the 9.pounder, in 18S7 made no effect wlatever on this blockhouse, or nothing to signify. I mention this no elowing the great ndrant:age in come circumst:nces of having heavier field guns. One can inagine what the cffect of slacll of this bind rould be in rillage fighting, where the church or the factors, obstinntely held by the enems, would be completely demolished hy the suclls of this new gun. Is regards aceuracy of practice, I mas mention our competitire prictice in 1899 with the 12 -pounder B.L.K. Eun. Two out of ten men struck s 6-foot square target al 1,500 sarils twice out of threc times, and sereral otlier men etruck it once. If this can be done we maj hope that thes would be able to strilie a machine-gun at thist ringe before the machine-gun could do them ans rery great injury. When speating of the practice of urtillers against zuisonrs, Culonel Halo 
rould like to know what effect it would hare. I do not think it would bo rery hard to hare masoney crected at Okclampton; it would be excecdingls interasting to sec the cbect of the different projectiles thereon, especially as in any European war there is a good desl of figliting done in and sbout rillage which aro frequently the turning points of actions. 'There is cne point which has not been noticed, and that is the effect that the use of aignalling should harc on artillery firc. Command. ing Ofiecrs frequently train one or two of their men to sigasl, but we haro no authorized eignallers in the batteries of our artillery. I thint there should bo an cstablishment of two cr thirce signallers in batterics of ficld artillery; they ought to be paid as ouch, and their status should be recognized just the saine as it is in the carnlry. Last jrar wo trained tro signnllers in iny battery, and I think tho practice was decidedly affected by the fsct that the obscrsing party and tho Comniandiug Officer could communicalc therebs with facility.

3Ir. NouDENFEIT : The paper is so full of intercsting and suggestite matter that we ehould take up a wock were we to discuss it fully. I want just to emphasize tho exceding neccseity of the rearrangenent of the Shocburgress Fstablishment. I hare done so once before last gear in this room. In France, the Marino Artillers, only for marine purposes, has an cotablishment of sirteen Oficers, who are working from morning till night. We, in Kingland, hare for both wcapons-Army and Nary -an establishment where, I beliere, there are thrco artillery Oficers, exceptionally clerer men, altogether orermorked, who have not only to carry out thege experiments for us but also to test smnuunition and slo nll sorts of things which ao one buruan being ean possibly do, and which they do their best to do. Surcly, instend of epending 20,000l. a.5esz on cxperinents nud getting s blowing-up in the Housc of Cominons, if you spend $200,000 \%$. I beliere thes would thank jou for it. In France, I belicre, they spend about 300,000l. on tho Morino Artillery alone. Tho question of smell calibre guns as againot lurge calibre is excecdingly intercoting. and I hope when the 8-pounder quick-firing gun comes to trial we shall hare some rery intercsting results. Prince Kraft ron IIolenlohe gires 3,800 jards as the range ut which shrapnel commences to hare effect, and from 1,500 to 2,000. 5ards as the period at which slirapncl is decisire. There is not the slightest doubt that quick-firing guns, be thes 6- or 8-pounders, are fully effectire up to 3,800 Jards, when they hare a decent initial relocity. I do not mean to eay thes haro tho ame effect as 12-pounders at the longest range; I do not ay that thes hare the samo effect against buildings, but I hould like to eee tho elfect of fifteen 8-pounder shots a minute containing mćlinite aguinst tro per minute of the ficld-gun. I do not think there will bo much difference on the whole. Colonel Meurico spoke of the suddenness of effect. I am norking with a rage.finder in which, up to 1,000 jards, wc hare an srerage fault of about per ccnt. That mesns, I can send up a range-finder beforehand, I can take a distance 2,000 or 3,000 jards awas; the encriy docs not see that process; I can then get up the battery or quick-firing guns, open fire for a minute or so at a range which I lnow within 1 per cent., sej thet it is 4,000 jardo-the fault would be 20 jards - I can fire minute fifteen or thirty rounds and gallop off again. I cannot imsgine ans moral cffect and also material effect greater than would be produced by firing fire times as many shells per minute, although each shell is onls 8 lbs. a agsinat 12 lbo. Fou canoot look out for tlices suclls, they come orer jou as a mass of fire. I beliero that it was mas. fire that I,ond Wolseley mant when he asked Mr. Maxim whether ho could make a machine-gun to fre lead bullets at a long rangc. Mr. Mrsim made ono $\frac{1}{2}$-inch calibre. Since tho 0.303 gires ouch excellent reoults for the distanco at wbich shrapncl is supposed to be decisire, personelly I do not beliere it is neces. anry to go to any other calibre, but with the range-finder when I can stand here, knoring $\mathrm{my}$ raogc, fire for a minule or two, then gallop to another point from which I also know the range by haring taken it at the prerious firing point, unlimber, firo snother ninute again, and then repcat the same somerhero clic, each time knowing the diotance, I am perfectls certain the result would bo worth atudy: ing. I would like to ser one word in all kizdnces. Ono of tho remarks Gencral Oren has put forward is that Major Mecham, at Aldershot, does not beliero in the firc of nuchino-guns. Mrjor Meclusm forgot in bin report to mention tho comparative time of fire. Tho machine-gun fired, I belierc, for one and a balf minutes, the 
infantry fircd for trenty minutes. Bcsides, I am not quite certain that a mustectry ingtructos, clerer and intelligent though $\mathrm{l}_{\mathrm{s}}$ be, is altogether abolutely unbiasicd as between rifles and otlier arms. I do not want to say a word againsi-Major Mechau, he is a elerer and experienecd Officer, but he is n inusleter instructor. I want to say one worl more about the quich-firing gun and machine-guns, and it is this : the new nowders we are getting are absolutely snoleles; that is to sny; the man who fires can sce througl tho liaze, but the cnems, if they are a mile awas, sce only the bluigh haze and cannot ace the inar: who fircs. These ponders are alio practically noiscless, at 100 jards or 200 jards frow the gun you hear a noise, hut no noise of any lind is heard 1,000 or 1,500 yards atway. Tlant menus that if I hare fount $m$ y range and fire for a minute, I $\mathrm{am}$ almost eatisfied that quick-firing guns or machine-guns will hare the required effect before the field guu is actually reads to commence to fire.

Yieutenant-Coloucl Scort, R.E. : General Oxen has giren us a verselear nnal interesting lecture on the ralue of artillery forec in the feld, in the liopes of convincing unbelicrers in its efficacy; but if he thinks that thes will be consinecd by worls nlone he is much moro sanguine than I am ; I hate already tried that gane. To be convinecd, they must go and witness with their own cyed the terrible coret of modern artillers fire on the practice ranges at Okchanpton, which pririlcge I liave inysclf enjoged by the courtesy of the kojal Artillery, for scrcrul yeurs, and then thes will change thrir opinions as did a rers distiuguished General Oflicer who, to the great satisfuction of the Rogal drtillery, honoured the eamp last summer with his presence. Tle knowlesige to be gained there, of the effect of artillery firc, of the modifying effect of ground upon the effect of that fire, and of the tactical principles to be learnt therefrom, the Qencral abure referred to would tell jun, is of the highest importance to erery Officer in the $A$ rmy, whether he be a commander or lcaller of men in the field. Ercre Ofticer who has completed bis course at the Staff College should be ordered to Olehaumpton instead of to Aldershot to learn artillers work. Do Olicer who has in clisinco of becouning a conmanter of troops will in thesc days be fit for such an important post who (as the lecturer has isell said) has not thoruughly mastered the tcchnichl and tactical raluo of cach arm, whether it be a ficld-gun, JIarim gun, quick-firing. gun, or riflo; for his gauge of tho effect of firs of cach of these arms crcates in his own mind the principles on which he is to buse his tactics, and if his ideas are thcoretical on this subject, his tactics rill also be theoretical, and rill scsult in an unncecssary sacrifico of the lires of his own men. 'There is only one way of acquiring the above most indispensable buowledge, aud that is to go and sce tlicse guns fred, and to note their destructive effects. "Ihere ecems to be present in tho minds of some that the field-gun un:u be supplauted bs onc of the new arm!, such as a Jarim gun or small calibre quick-firing gun. Now I am not one of those who think that either of them can take the plice of the otier. We want them all, and as mans of them ns possible. 'Thes each liare an independent róle 10 plag, und it is our bitsiness to find out by actual practice what that role is, so thitt we may intelligently combine their forces together to the best adrantanc, under different pbases of the fight. If it comes to n comparison betwecn the ralue of the Marim machine-gun and the 12.pounder ficld-gun, as an engine of war, tluere is no question in mr unn mind that the fieldgun lias the paln. The ficld-gun, with its shrupnel containing 177 bullets, its cuse containing 210 or more bullets, its common shell and frugments, cun creatc agitinst troops in the open as deadly a danger zone of bullets at 4,000 yards as the Maxim gun can at 1,000 or 2,000 , if the ctfect of its fire can be obecrichl, nnd it cun attuck troops behind corer with effect with it shrupnel and common shell which: the machine-gun cannot; and at cloec ranges it cau fire its case with 216 bullets with deadly effect up to 300 Jards. How often has it hoppened that the infantry conld not penet rate into u rillage or house till the artillerg lind conc up to their assistance. With a rice to conrincing any unbelievers in . the value of artillery firc; I would remind them that rhen a shirapnel is burst at the proper distauce from troops in tl : open, the cone of dispension of shrapuel containing 177 bullets creates a ding $r$ zonic on lerel ground of 140 sards long by 26 jards broad at 1,000 surds; of 330 jards long by 20 yards broad at 2,000 Jands; and of 160 yards. long: by 'I3 gards uned at 4,000 sards, and tlint, contrury to tho niachine-gun fire, the fro 
of the danger zone is more intense at the longer ranges than at the sho:ter range, because the 177 bullets of tho slirapnel fall into a smaller space. No, gentlenter, artillers fire is no jole in thicse days. The hole made by a shot is no lunger the safest place to put rour hesd into in these class on lamd. I do not know whether this practice atill obtains in the Jiars. The le-pounder shoots lite a rifle, and, in fact, shoots where it is laid. Fou won't beliere we, perhepe, when I tell jou that jou can hit a gun in about three shots at 3,000 yards, and thiat shote frequently go tlirough the eame hole. With the slow-firing horitzer, I have mysclf secn at Shocburgmess three shots go througli the eame hole nt 2,400 Jirds, and if that can be doue with a howitzer, the slow trarelling shot of which is more influeneed of course by the air than that of a high relocity la-pounder gun, then it can casily be dome by the high relocity 12-pounder. There is another point which General Owen Juen. tioned with referenco to $a$ battery first coming into action, and theu finding the range. I think so highly of the effect of artillers fre, that I do not beliere a batters could come into action aguinst another battery already in action without being annihiIntel ; sad, therefore, I think it is absolutely necessury that the ranged fliould be found first of all by range-finder, or by a ecction of gums, and the eights uljusted under corer, the gun loaded and tho fuze act, before going into action. Of course thera are difficulties at present about haring the gun loaded, but I beliere that it conld casily bn got orer with a little thought; also you want tho fuze to be in the base of the ehell which can bo altered after the gun lias becu loadcd. 'There is another point, that is with refercace to the lecturer's resnneks on the ralue which Lord Wolseles is said to put on artillery. I renture to think that his lordship's impresions on that point were rery similar to those helel by a large number of artillery Oncers themselres, prerious to tho important improrcuents which liave recently been introduced into tlie training of the Oliecrs and men in slooting. and I am suro no oue in Fingland would bo more plensed than his loxdship to learn that the artillers fire had eo much improred, and that the artillery intends to maintain $t t_{1}$ proud position for cticiency which it has always held in the British Army. Yerhap sou are not arare thal it was cntircly dluc to Lord Wolsclcy's iuduenec that tho eights which General Owen has been good enough to refer to in his lecture were tried by batteries of ficld artillers, and if they hate met with your approral, it is his lordship that sou hare to thank for their introluction into the Serrice.

Sajor IIrtrox, liing's Royal Rifles : Jy remarls mado at Aldcrshot, to which General Ovien lias alluded, were intended to convey tho idea, and, I think, they did in the discussion which followed the lecture, that the machine-gun which we Jave had an opportunits of testing up to the present moment is not a perfect wcapon, and not that machinc.guns are not cxtremcly raluable adjuncts to an army in the ficld. 'The experiuents conducted at fldershot under ihe superintendence of Major Jiecham, to whom JIr. Norlenfelt referred, were conducted with rery grcit care, and, as far as possible, uncler serrice conditions, and tho result certainly surprised erery one. Cteneral Owen has alladed in lis lecture to the result of the caperimental practice which then look place. 'Tlic rinson that the shooting was so bad we considered to ariso from the fact that the sights and mechanism of the guns under trial were defeclive. The question of the principle of the employment of machine-guns with troops did not come into the question at all, but as practical soldiers we considered that the machine-gun subunitted for trial was not a perfect onc. I do not think there can be any difiercuces of opinion as to the extreme value of the machiue guns in war, firstly, at eliort ranges, and, sccondly, at long rangcs. It is sinply a question whether at long ranges tlie muchinc-gun is a sufficicutly perfect and fuished wcapon for it 3 purpese. I renturc to think that at the present moment it is not so. Some very remarkable cxperiments took place at Sldershot the other day, which illustratcd or brought liowe to us one of the manifest defects of the machine-gun at lollg runges. The new mingizine rifle was fired at 2,500 yurds by 2 party of nincts infuntry soldiers at a rertical and horizontal target with the unost ext raordinarils euccessful results. The target was not secn by tlic men at the liring point, as it was a tery foggy das, but they directed their aim at an interinediate point at 1,000 yards distance, but here lies the secret of the sucessful shooting; the dircetion of cicrs rolles, and the mistales 
made in the ain, were made known accurately at the firing point by means of the telegraph, and thercfore tho nccessnry resdjustment of sights was made, and thus it was that the shooting was so extremely accurate. Hear in mind that with a machine-gun you hare no means of occing whero the bullets strike, and therefore: unless you hitre a very carefully contrired range-finder, jour machine-gun may be pumping lensl and cxhausting the amtrunition limbers to no purpose rhiuterer. Again, tho lajing of the gun and the sighting must be of the most perfect and complete bind if uscful practice is to ba recloned upon at long ranges.

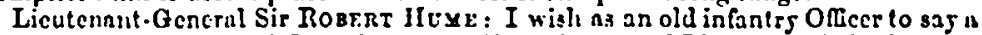
few words to tell General Oren how excecdingly interested I hare been in his lecture, and also becausc I do not thiuk any infantry Onicers lare spolen this erening. The subject of the lecture is of the greatest interest to us, more so perhaps that to artillery Officers, who naturally know so much moro about tho subject than wo do, but it is cerlainly of quitc as unuch as great intercst to us as it can be to thein. I have never in the course of my serrice heard so manj nbserrations made in, I may say, depreciation of the artillers as I harc heard this crening, I inean that flic opinion sceins to be pretts general that in ofher brunches of the Serrice the artillery is not appreciated. Hut that is not at all the fact. 'There is no branch of the Serrice that any of us, I think, are more proud of altogether than our artillery, and I an perfectly ccrtain that anj of us, cither infuntrynen or caralrsuncn, would be very morrs indeed to hare to slepend upon ourscires and to be left without artillers. Is for the moral effect of artillery, I do not thint, solong as the artillery produecs the effect that we wish it to do, that it matters whether it is moral or whetber it is actual. I do not know whether there aro anj other OMicers in the room who can remember une instanee of the rer orerwhelming effect of artillers. that wo eaw in the Crimea, I mesn at the Alins, when we were going up the hili. 'Wiere vere three shells. fired from Turner's buttery into what ecencel to us an enormous mass of Russisns who were coming down the hill, but the effect of those three shells dropped into this mass, whether it ras morsl or whether it was actual I do nol know, was that the mass mored up the hill, and the effect on our men was that they went faster up the hill after that mass than they had done before. That happened wlien I was a joung subaltern, and of course a fen things of that sort in the way of practico have rery great effect on one's mind. I lnow that any of us who serscl out therc, and scteally sar the elfect, and felt the effect of artillery, hare nerer doubted the ralue of artillers eince those dags, and we teuch, as far as we can, our nell of different branclics of the Scrrice what thes are to expect from tho assistance and also from the opposition of artillery. With reference to nilat the lecturce said as regards Oficers as fur as posible being instructel or going down to seo experiments with artillers at Shocburyness or whererer they niay be, I thinl that the different branches of the Serrice sbould, as far as possible, wliencver opportunity offers, be made acquainted witl the arms and with the training of the other branches. In India, where I serred a lons time, we haro many of thoso opportunitics which jou cannot li2ro in England, because we are ablo in carrs out our own artillery practice, and our rifle practice near our large etations whero any man, it docs not matter whether lie be a General Onicer or one of the prirntes, infantry or carnlry, can go to the range, and nuny do go to the range, and sec the effect of tho pratice. Witl regerd to another obscr. vation made about artillery Ofliscrs malin: a mssters of their guns, and alat tlicy hare to do, I ean only eny in my crperience, and I hare had a good deal, I hare nercr ecen it. I hare found the greatest ansicty, not only to show eversbody what they have to do, but to fet men of other branches of tho Serrice to go and ace what they are doing, ond the greatest pride tsken in shoming what thes cando. I am delighted to hear. all that lius been said to-day about the progress the artiller! is making, becult:c so much depends upon it, and I feel personalls rers much obliger to the lecturer for tho lecture be has giren us, and the opportunity of the discussion. To nians of us wlio are not actirely cmplojed, this Institution is the onls place whero we can hear these subjects properly diecusecd.

Cuptain F. E. 1). Acc.tSD : I shall not detain the mecting for more than a for snoments, but as an old Sliocburgncss Officer, and haring spcut orer four yeses in experimestal work, I should like to say a mord ox i wo in regurd to what (temeral 
Owen said. Firstly as to firing guns on what I think he culled "perfectly lerel ground." As an cxperimentalist, I am convinced that it is the only way to arrire at ang true results whuterer with machine-guns or other artillers.matcíricl; and to arrive at anj reliable conclusion as to the conneratire accuracy of ans $\mathrm{kcapon}$, crery outeide cause of possible inaccurney inust first be carefully eliminated. Ifter the weipons huve passed through the experimental stage thes should of cuturso be havded orer to the troops to experiment with them in what is technically known as "under acrice conditions." I know what an experiment under eerrice conditions meuns, because I hare carricl out wany in that was mysclf; but I fear that it often meand that insuficient care for details is hestowed on it, and, cren if the care is giren, the Otficer who has charge of the esperiment cloes not fully grasp all those points of cletuil which arc inatters of ordinary routine to a man witl a regular expcrinsental training. For instance, Jiajor Hutton has just fallen into a tray), in which I must catch him. II has told sou that with the new rifle and the new ammunition thes fired with most wonderful results at 2,500 yards, and that they bad the effect of their fire and 80 on telegraphed down to the firing point, and then inmediately, in the next sentenee, he anys that with the machine-gun you cannot sce the result of jour firc, and so liow can you erpect to get cffectire shooting at thesc long ranges? The logical conclusion would be to put the machine-gun on a footing similar to the rifle, and establish tho telegraph, und then jou hare a fuir comparison between the two. After an cnormous anount of trouble in rarious quarters ther bare at last arrired at an ammunition for the new rille, but as far as $I$ know there is no machine-gun built at the present monent which hins crer fircl that ammunition. If you want to compare your riflo and machinc.gun fire, put them on an equal footing in this respect and fre similar ammunition, and so sce which is the most accumle. I nust nlso go bark to a remurl made by $\mathbf{~ I r}$. Nordenfelt as to the experimental cstablishnents of this country. Since I hare left the Serrice it has been ins pririlege to see the experimental departnests of two of the larger liuropesn countrics, Austria aud Russia. I liad always, as a truo Britisher, expected to find Ruezia a benighted country, but I must own, to my shame, that though I found tho Odicers less weli cducated and less well up in wliat one might call Luropean gunners, yet their cxperiacntal cstablisliment was ccrtaiuly double if not treble ns good ns our own at Shocburgness. Their instruments were perfect, and if money was wanted and the experimental Oficers said that thes must hase certain things thes eceued to get them. The experiments were carricd out by a stiff of ezilors and soldiers, not of soldiers only for naral experiunents, but of soldicrs and sailors, eacli doing their own proper work, and doing it in a way which was a source of astonislintent to me. lis Austria it is much the same thing: cach haro their own experimental ranges and establishments. Now I am perfectly intimate with all the details of Shocburyne:s wort, and I say it is monstrous that in this country, with all its wealth, we should be left with one questionably complete expcrimental establishnent, inferior, as far as I can judge from a mecl's risit to one place and a fortuight to the other, in almo:t crery respect to those in Austria and in Russia."

General Owex : I shall trouble you with verg few remarks in reply. The object of the lecture was to clicit inforumation from others ratlies thun io uttempt to instruct anjbody herc. I wanted to hear the obscriations of those interested in the rarious points raied. Colonel Markhan said that my paper deslt ratiner with thic histors than the ralue of Geld artillers, but I think the discussion we hare hacl will hardly bear out that criticism. I saw Mr. Nordenfelt the other day, and be was good enough to tell me there was an 8-pounder besicles the 6-pounder. If it is an 3-pounder so mucls the better; but I understood Jir. Nordenfelt to recommend the 6.pounder. Colonel Markliam said that I had not pointed out the best places for limbers und ragons in action, but it night be inferred

1 I am perfectly well aware of the ceperimentnl establishment conacted with the "Excellent," but it must from local clisadrantages remuin lamentubly deficient in all that can make it a eatisfactorg place for scientific rescurch into general gunnery questions, which is rital to the correct solution of those mans problems connected nith inatericl before it is introduced into the Naral Serrice. 
from what I did sur, that theso should be in rear of the interrals betrecn the guns, out of sight, nind under corer when possible. Is to the int ruduction of field howitzers and taking steps to aroid the necessits of turning fftech field batteries into ammunition columns, I shall be extremely glad to hear if both can be accomplished; but the 20-pounder lately tried at Okehaupton is not a howitzer in ans way. The guns supplied for the reserre forecs are rery uscful, but ther aro mostly position gune, Whicli woult in no war be able to tako tho place of ficldeguns. It is not. itecessary for me to answer rhat Colonel IIsle aaid; Captain Sultmarsh replied vers effectirely. I da not think there is much doubt that buildings or etrone masonrs of anj kind would be damaged rers considerably by our gune. Coloucl Maurice put rery ably tho contention respecting tie moral effect of artillery, but I cannot at all amrec with him that the moral cflict is out of all proportion to the setual cfect. Howerer, it is not worth while eajing anything more about that point, hut I may say this : Colonel Ilome's book on "ructics," nlthough written n long time ngo, is still used. 'Ilıcn ugain with Jegard to Lord Wolseles's "Pocket Book," - I did not quote the clition he published twents years nzo, but tho eighth edition. Sir Gernlal Graliam took execpition to what 1 said about continuouslscoutinuously fired from the same position vithout recoil. What I say is, you cannot firc a gun coutinuouslr that you hare to lay betwecu the rounds; you cannot fire a luundred rounds continuously if you hare to lay your gun between each round. I am not spealing of the Inxim but the quick-firing guns, and I understood, both from the Arnstrong frum and from Jir. Norilenfelt, that the firing of cuch round put out the lising to a certnin extent; that although the recoil carriage prescnted ang running bick, and thero was only a slight motion, still there was suflicient to put out the laving.

Mr. Nondexrext : 'The vibration of the wmpon is eufficient to disturb the aim at 2,000 or 3,000 yards ; therefore they should always be relaid. But the relaging is done by whecls, and we still fire from fiften to cigluteen rounds comfortably per minute by relaying cach round.

Qcneril OWr.x: $1 \mathrm{an}$ glad to hear that so much can be donc.

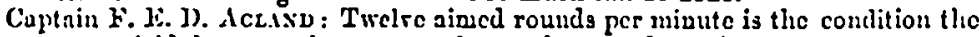
Gorernment laid down, so that jou can lay twelre rounds s minute.

General Orw: : Captain Stone said the reasen for haring the bursting cliarge of shrajmel in the head was that it enabled the shell to be fired with a percussion fuzc. I an not quite sure I understood hin, but if that is the case, it is an aclran. tane, of course; still I commot think that the shell is altogetber eatisfactory, nmel when I wrote to Colonel Barlor, K.A.. Superintendent of the lloral Luboratory, to ask the renson, he replied, "Having the bursting chargo in the head leures room for more bullets."

Captain Srose : I said that putting the charge in the head enabled the bursting chisge to be ignited with greater rapidity thnn when it was in the base, and that therefore pereussion shrapnel would take effect under the new conditions with meat results up to 2,000 sards; whereas in the old condition, that is, when the fuze took so long to ignite the burstiug elarge, owing to tle latter being in the basc, the bullets went up in the air instead of trarelling forward. This is due to the fact that in tho former casc, the burst is almost instantancous upon impact, and actually takes place at the woment when the effect of the ricuchet has brought the axis of the shell into s horizontal position, or with its point perhajs just on the riso from that position; the asis of the cone of dispersion is conscquently horizontal or sligbtly inclined upwards, thus giring great cffect to the bullets. In the latter case, howerer, the action of ricochet is completed before the burst lias time to take place, the result being that the axis of the cone of dispersion is deflected upwards to such an cstcat, that there is practically a sufcty zonc of 50 to 100 sircls immedintely in front of the proint of impact, nost of the bullets falling harmlessly over the objest aimed st.

Generil Owex: Jr. Tordenfelt said the perder they used would make rery little noiec and no smoke, but a lind of haze, which would be mather an obstruction in the way of those aining from a distance. That of course is an adrantage, and I referrcl to it in ens paper. As to $\mathrm{my}$ alluding to at fallecious couperioon in counting the amount of netal fircd frow two guns, I say this, if you bare a 
G-pounder slicll fired against a 12-pounder sbell, for instance, the smaller shell, I should imagine, would fire too cloee, and the cone of dispersion would not be of the sane cxtent. You may fire the samo reight, but jou would not corer tho asmo ground-that is my nicaning. I do not think it is necesseny to detain jon any longer.

The Crrsirax (Sir Lintorn Simmons) : I thiuk rou will all agren with me, in fact all the spealers litherto have expressed their opinions that thes lase been much gratified by the lecture re liare just leard from General Owen. It has brouglit sumdry subjects under our notice which are of great interest to the Services. Thes are so numerous that it will not be possible for me to touch upon many of them, but there are one or two as to which I will male a few obserrations. The lecturer in the first instance began $b_{j}$ combating a etatement by I.ord Wolscley, that the cficet of artillery is more morul than actual, and that it hills but fow. I harc heard a great deal about moml cffects as distinguished from actual cffects, but my belief is thast the moral follows the actual results, and that noise will not frighten properly organized troops, stuch as an army night be likels to meel in livrope, but that thes are effected golely and wholly by the rcsults that are to be scen unong them. There is a certain elfect of noise which gires conflewec to troops, as when their own artillery is heard in their ricinity, because it assures them that they are supprorted on their Dank, where thes know that destructive results are bcing produced upon tho enemy. The effect of the noiso of artillery in the field is not like that produced upon a honsehold when a burglar is in the housc, who inay be suspected of haring a rerolver in his poclet. Indiriduals are liable to alarms of that eort, but I do not belicre that large masscs of men, if well tratined, well orgauized, and eubject to discipline, can be atfected in that way. What realls brings crusbing effects in war is when troops hatring been weatened by liscasc, by heary marclies, br want of food, or by previous disasters, find thes arc suffering lieirs losses; great moral cffects are then produced, and rhen to fatiguel and worn out that they are unable to maintain their ground. These, I beliere, are the principal causcs why troops retire from the field of battlo; but I do not belierc in the woral effect of noise at all. The question of quick.firing guns is one of the greatest possible interest. I heard Captain Acland remark that the conditions fised br the Gorcrnment for quick-firing gung werc that they should be able to fire twelre daid rounds in a minute. That is, I presume, for sca serrice; aud I ciu perfectly understund such to he the case, because at sea gun are fixed upm standards when they do not recoil at all, which is not the condition of guns which must be subject to recoil or shock when fired in the field. I take it the conditions are quite different. Huring scen practice on board sbip, I have not the slightest donbl that these guns can be fired trelre rounds in a minute, the gun being in a fiscd stable position, and tho man who lays the gun nerer removing his slooulder from its butt.

Captain Acc.1xd: If the field-gun clocs not rccoil, surcly the guns are in the sawe condition as those on boart slip?

The Citsinses: : But in the field the gun is not fired from a fixel platform.

Captain $\Delta$ CLs ע : 'Tle gun will not recoil.

Thic Charusax: On board ship the gun is absolutely fised, and the platform to which the gun is attached is fired; whereas in the field there must be e certain umount of motion from the shock on the ground. I hare not ecen these guns at work in the ficld, but I cannot understand that there is no motion whaterce on the ground.

Jir. Wordesfelt : We hare often fired cighteen rounds from a feld carriage often.

The Curajusrax : Laid?

Mr. Nondr.xelt : Yes, often.

'The Crajrysx: I nm glad to hear it, but I do not understand it, I must sas, that is, if the gun be carefully laid after each round. Then as to the effect of shripmel in the ficld. I hare not secn any of tisese new pattern slirappel with bursting charges in their head, but haring becn on the Armstrong and Whitworth Cummittec, which is now perhaps almost too out of datc to allucle to, I hnow that slirapnel shells of those dass, as fitted be General Boxer, had the charges in the 
baec of the shell, and that a great number of rounds were fired dircet at walls 18 or 20 inches thick, and againat carthworks, when we found that the eliells with tliose pereussion fuzes exploded immediatcly behius the obitacle, as thes canic out of it, within a couple of feet or so. The results, as recorded, show that thes rould haro had the most destruetire effect upon men inside the walls. In order to test the action of the fuzcs, which was very quick, shells were fired against tarfets of wool 2 inclieg thict, after passing through which, they burst about 15 fect behind thein, at lenst that was the conclusion that wus arrircd at after a number of esperiments carcfully conducted. That scens a rery quick explosiou, and certainls the bullets were not impeded bs it, which thes must be, inore or less, bs the explosion of the charge in tho kead of the ebcll. I bare no further obecriations to make. Tlucse lase occurred to me rithin the laet fer minutes, and I now ast jou to pass a rote of thasks to General $O_{\text {red }}$ for hi3 crecedingly interesting lecture. 